\title{
PUBLIC SERVICE SPENDING: EFFICIENCY AND DISTRIBUTIONAL IMPACT- LESSONS FROM ASIA
}

Rouselle F. Lavado and Gabriel Angelo Domingo

NO. 435

July 2015
ADB ECONOMICS WORKING PAPER SERIES 
ADB Economics Working Paper Series

\section{Public Service Spending: Efficiency and Distributional Impact-Lessons from Asia}

Rouselle F. Lavado

and Gabriel Angelo Domingo

No. 435 | July 2015
Rouselle F. Lavado (rlavado@worldbank.org), a fellow at the Philippine Institute for Development Studies and Institute for Health Metrics and Evaluation at the time of writing. Gabriel Angelo Domingo

(gbdomingo@ucdavis.edu), a PhD candidate from University of California, Davis.

This was one of the background papers prepared for the Asian Development Outlook 2013 Update theme chapter on Governance and Public Service Delivery. 
Asian Development Bank

6 ADB Avenue, Mandaluyong City

1550 Metro Manila, Philippines

www.adb.org

(C) 2015 by Asian Development Bank

July 2015

ISSN 2313-6537 (Print), 2313-6545 (e-ISSN)

Publication Stock No. WPS157452-2

The views expressed in this paper are those of the authors and do not necessarily reflect the views and policies of the Asian Development Bank (ADB) or its Board of Governors or the governments they represent.

ADB does not guarantee the accuracy of the data included in this publication and accepts no responsibility for any consequence of their use.

By making any designation of or reference to a particular territory or geographic area, or by using the term "country" in this document, $A D B$ does not intend to make any judgments as to the legal or other status of any territory or area.

Note: In this publication, “\$” refers to US dollars.

The ADB Economics Working Paper Series is a forum for stimulating discussion and eliciting feedback on ongoing and recently completed research and policy studies undertaken by the Asian Development Bank (ADB) staff, consultants, or resource persons. The series deals with key economic and development problems, particularly those facing the Asia and Pacific region; as well as conceptual, analytical, or methodological issues relating to project/program economic analysis, and statistical data and measurement. The series aims to enhance the knowledge on Asia's development and policy challenges; strengthen analytical rigor and quality of ADB's country partnership strategies, and its subregional and country operations; and improve the quality and availability of statistical data and development indicators for monitoring development effectiveness.

The ADB Economics Working Paper Series is a quick-disseminating, informal publication whose titles could subsequently be revised for publication as articles in professional journals or chapters in books. The series is maintained by the Economic Research and Regional Cooperation Department. 


\section{CONTENTS}

TABLES AND FIGURES

ABSTRACT $v$

$\begin{array}{ll}\text { I. INTRODUCTION } & 1\end{array}$

II. $\quad$ TRENDS IN PUBLIC SPENDING IN ASIA 1

$\begin{array}{ll}\text { III. } & \text { EFFICIENCY OF PUBLIC EXPENDITURE }\end{array}$

IV. METHODS 12

A. Data Envelopment Analysis $\quad 12$

B. Malmquist Data Envelopment Analysis 19

V. THE EFFICIENCY OF SOCIAL SERVICES EXPENDITURE IN ASIAN COUNTRIES 20

A. Data 21

B. Issues in the Estimation $\quad 21$

C. Health and Education Efficiencies $\quad 21$

D. Efficiency Change over Time 24

E. Explaining Efficiency Scores 29

F. Method 29

G. Estimation Results $\quad 29$

VI. DISTRIBUTION OF PUBLIC SPENDING

A. Inequalities in Utilization $\quad 34$

B. Inequalities in Government Subsidies 36

VII. CONCLUSIONS AND POLICY RECOMMENDATIONS 38

$\begin{array}{ll}\text { APPENDIX } & 41\end{array}$

$\begin{array}{ll}\text { REFERENCES } & 45\end{array}$ 


\section{TABLES AND FIGURES}

\section{TABLES}

1 Overview of Previous Studies on Benchmarking in the Health and Education Sectors 10

$2 \quad$ Hypothetical Province Data 15

3 Hypothetical Rural Health Centers Data 16

$4 \quad$ Technical and Scale Efficiencies of Regional Health Center 17

$5 \quad$ Input and Output Variables 21

$6 \quad$ Health Expenditure Efficiency Scores, $2010 \quad 22$

$7 \quad$ Education Efficiency Scores, Average from 2006 to $2012 \quad 23$

$8 \quad$ Expenditure Efficiency in Asian Countries 24

9 Productivity Change in Health for ADB Member Economies, 1995-2010 25

10 Productivity Change in Education for ADB Member Economies, 1995-2010 27

11 Government Health Expenditure, Outputs, and Productivity Change

for Efficient and Inefficient Economies $\quad 27$

12 Government Education Expenditure, Outputs, and Productivity Change

for Efficient and Inefficient Economies 28

13 Correlation Coefficients of Independent Variables 29

14 Regression Results: Factors Affecting Expenditure Efficiency Scores 30

15 Equity in Full Immunization Utilization 34

16 Equity in Skilled Birth Attendance Utilization 35

17 Equity in Outpatient Utilization $\quad 35$

18 Equity in Inpatient Utilization 36

19 Benefit Incidence of Public Expenditure on Health, Selected Economies and Years 36

20 Benefit Incidence of Public Expenditure on Primary and Secondary Education, Selected Economies and Years

\section{FIGURES}

$1 \quad$ Public Spending on Goods and Services as a Share of Total Government Expenditure versus Income per Capita 2

2 Health Expenditure as a Share of GDP versus Income per Capita, 2010

3 Public Education Expenditure as a Share of GDP versus Income per Capita, $2010 \quad 4$

$4 \quad$ Change in Government Education Spending (\% of GDP) 4

$5 \quad$ Change in Government Education Spending (\% of total expenditure) 5

$6 \quad$ Change in Government Health Spending (\% of GDP) 5

$7 \quad$ Change in Government Health Spending (\% of total expenditure) 6

$8 \quad$ Change in Government Social Security and Welfare Spending (\% of GDP) 6

9 Change in Government Social Security and Welfare Spending (\% of total expenditure) 7

10 Constant Returns to Scale and Variable Returns to Scale Data Envelopment Analysis 14

11 Illustration of Data Envelopment Analysis Methodology 15

12 Illustration of Data Envelopment Analysis, Variable Returns to Scale 17

$13 \quad$ Illustration of Input and Output Efficiency 18

14 Health Expenditure Efficiency by Region, 1995-2010 24 


\begin{abstract}
Efficiency and equity are cornerstone concepts in rational service delivery in the public sector. This paper benchmarks efficiency and equity in public spending on health, education and social protection in a broad group of Asian Development Bank (ADB) member economies with varying levels of development. We describe public expenditure trends in health, education and social protection in the region. Following Herrera and Pang (2005), we conduct a formal efficiency benchmarking exercise using Data Envelopment Analysis and available input and output data from WDI, GFS, and ADB databases to deconstruct each member economy's efficiency changes in health and education spending. We next turn to review service provision inequality within ADB economies using utilization rates and benefit incidence, and note the deficiency of pro-poor spending in some sectors.
\end{abstract}

Keywords: governance and institutions, MDGs and inclusive growth, poverty, social protection

JEL Classification: H51, H52, H53 


\section{INTRODUCTION}

The two major goals of public service spending are: (i) achieving targets (i.e., MDG goals) at the lowest cost through an optimal mix of inputs, that is, efficiency; and (ii) ensuring that public services reach those who need them most, such as the poorest segment of the population, or equity. Decisions of policymakers on where and how to spend have important implications on both efficiency and equity.

Efficiency consists of two components-allocative efficiency and technical efficiency. Allocative efficiency looks at finding the cost minimizing mix of inputs to achieve a certain level of output. For instance, many studies in the 2006 Disease Control Priorities Network publication indicated that public health interventions are more cost-effective than curative-inpatient and outpatient visits. Technical efficiency looks at minimizing the total cost of inputs to achieve a given level of output. Most of the literature on the efficiency of public expenditure focuses on analyzing this concept, particularly on the cost differences of achieving a certain level of output which may be different across countries or across subcategories in a given sector.

In many countries, the public sector is heavily involved in providing education and health care. Hence, to maximize return, it is crucial that countries provide these services at a certain level and quality, and at the minimum cost.

There is also concern regarding equity in public spending. On the one hand, this reflects the belief that the government's role in society involves some redistribution toward groups and areas that require development and aid. On the other, there is an increasing realization that allocative efficiency can be improved by allocating public money toward the poor or neglected groups'.

This paper is organized as follows. Section II presents trends on public expenditure in Asia. Section III shows a framework for analyzing expenditure efficiency using data envelopment analysis. Section IV looks at the distribution of public spending, and Section $\vee$ concludes.

\section{TRENDS IN PUBLIC SPENDING IN ASIA}

On average, the share in the total budget of government expenditure devoted to goods and services declines in 2000 and 2010 (Figure 1). Notable decreases are observed in the Kyrgyz Republic, Pakistan, and Maldives. Plotted against the share of income per capita, the share decreases as income rises. Countries that are spending below the average for their income group are Nepal, India, Indonesia, and Japan. Outlier countries, where budget shares are twice or thrice those of other countries with similar incomes are Afghanistan and Maldives.

\footnotetext{
Reallocating expenditures and resources across rich and poor districts to lower average cost of provision is a theme in
} many Public Expenditure Reviews. 


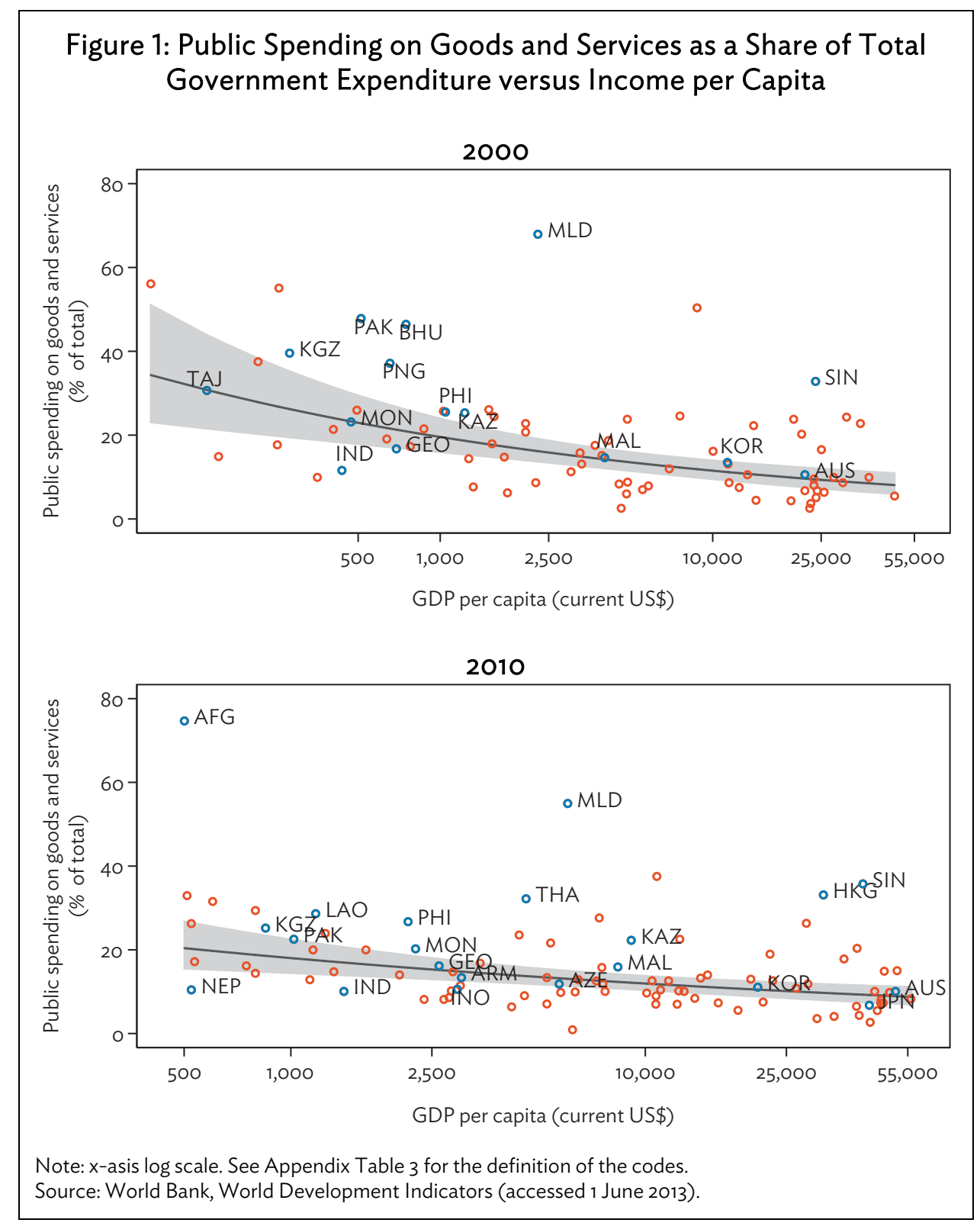

At least half of Asian countries spend less than $5 \%$ of their gross domestic product (GDP) on health (Figure 2). Studies (James, C. D., D. Bayarsaikhan, and H. Bekedam 2010; WHO 2010) have shown that on average, countries that spend $5 \%$ and above of their GDP on health achieve better financial risk protection and exhibit good population health outcomes. Countries spending above 5\% are predominantly island countries like the Marshall Islands, Tuvalu, Kiribati, and Palau as well as Organisation for Economic Co-Operation and Development (OECD) countries like the Republic of Korea, Australia, and Japan. Countries with the lowest total health expenditure relative to their GDP per capita are Bangladesh, Pakistan, and Singapore. Spending increases with income for both total and public spending on health. 


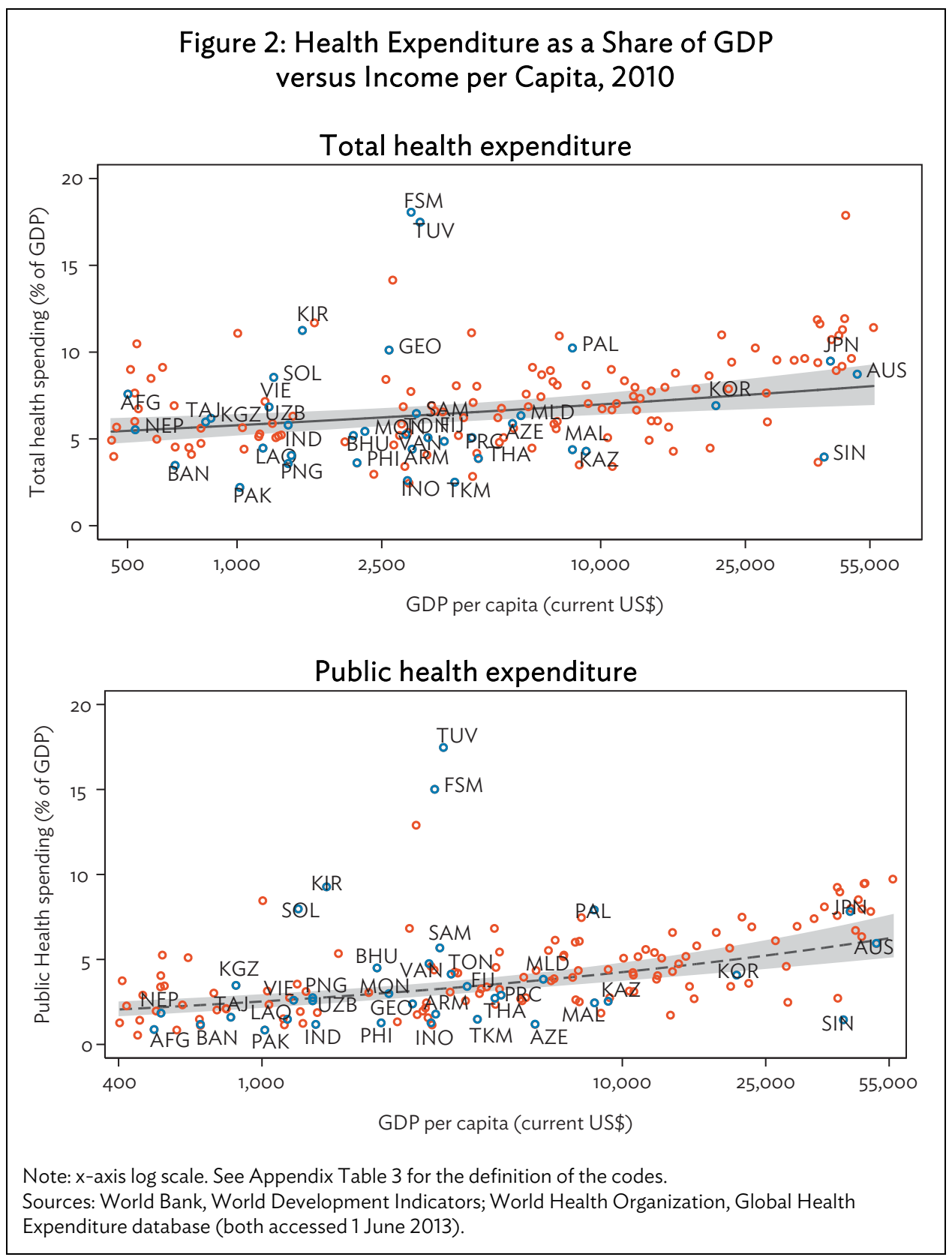

Unlike health, education expenditure as a share of GDP remains relatively constant across incomes (Figure 3). Asian countries who are spending above the average are Solomon Islands, the Kyrgyz Republic, and Mongolia; while Pakistan, Armenia, and Azerbaijan spent the lowest, compared to other economies at the same income levels. 


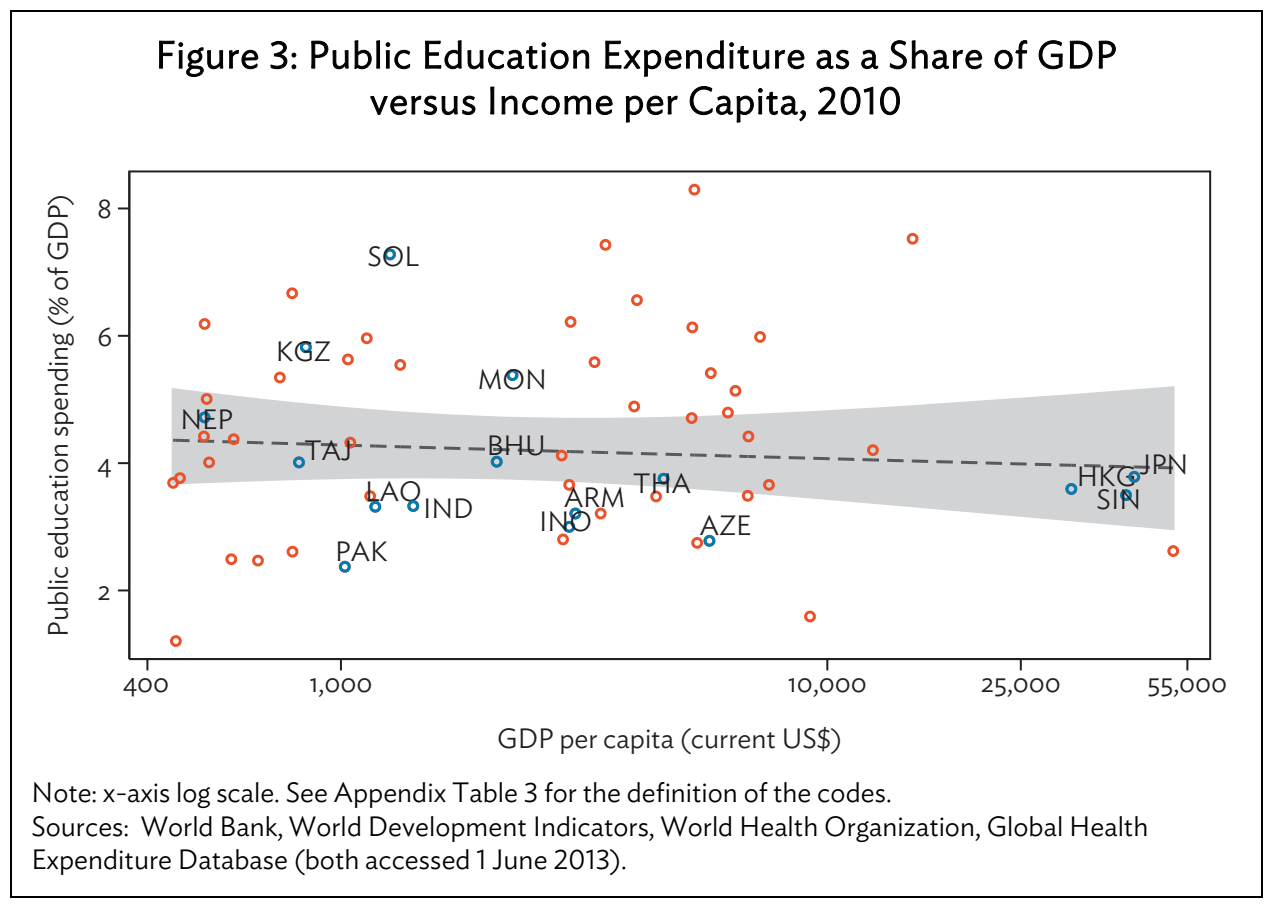

Figures 4 through 9 illustrate the changes in public expenditures in education, health, and social protection in various economies. Spending on public education show some convergenceeconomies starting with a larger share before 2005 tend to see their spending (as a share of GDP or as a share of total government outlay) shrink and those with a smaller share tend to rise. Timor-Leste, Armenia, and Samoa's education share (GDP and total budget) grew over the decade, while Mongolia, Brunei Darussalam, and Azerbaijan's fell.

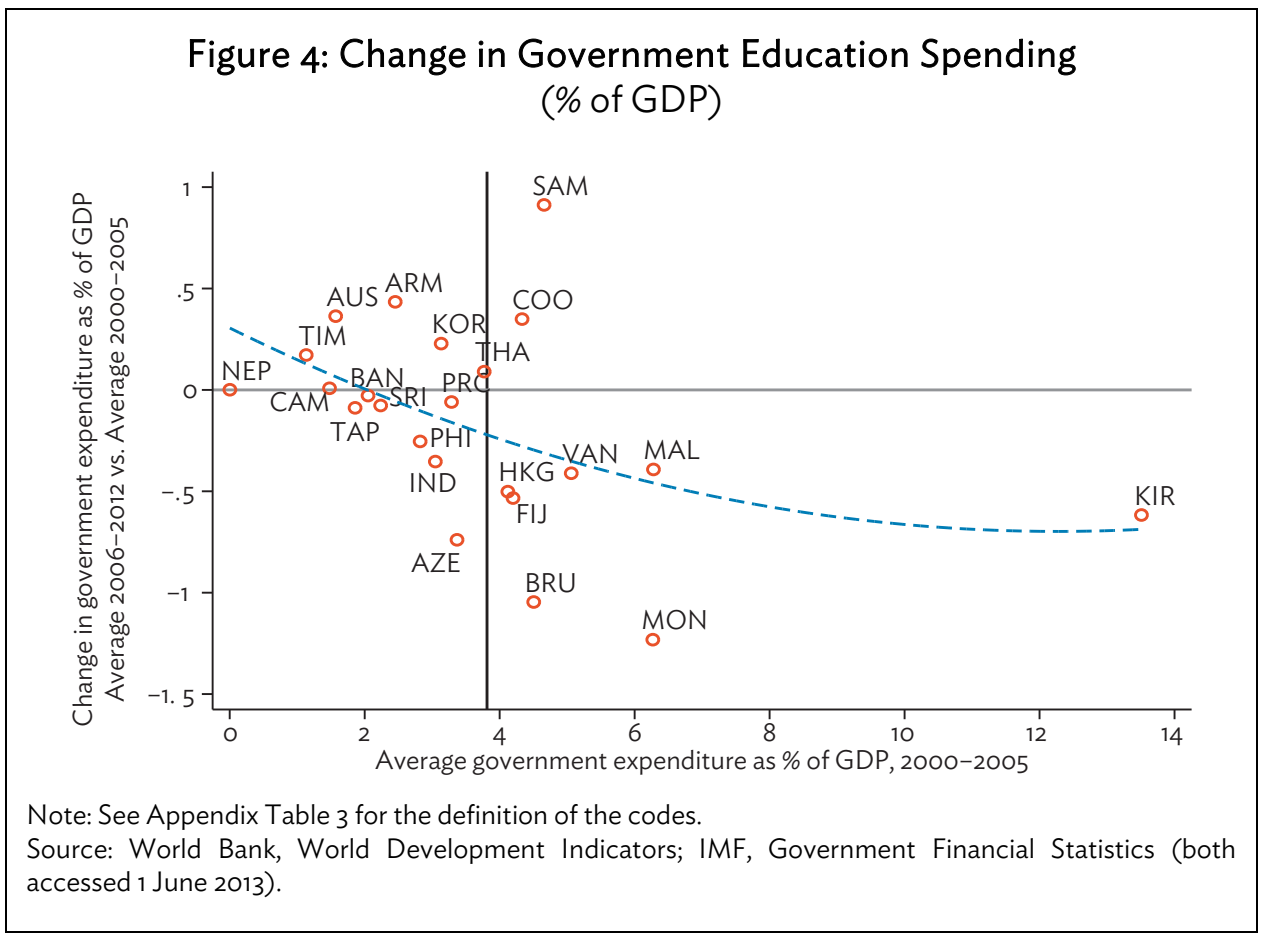




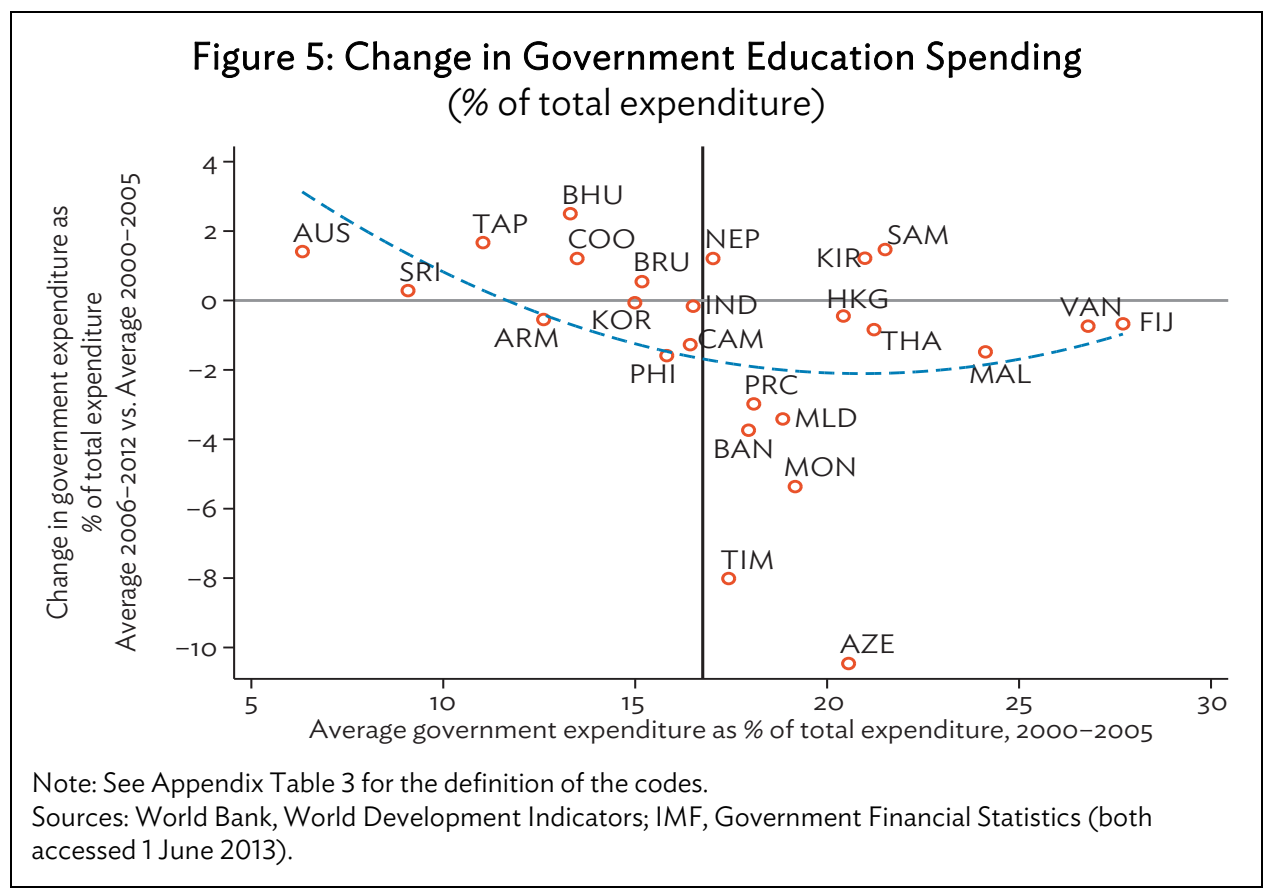

Most economies in the World Development Indicators database experienced an increase in health spending as a percent of GDP, even those starting with a larger share of spending of either GDP (Figure 6). The countries that showed the largest increases are Thailand, Armenia, Samoa, and Kiribati; while Brunei and Mongolia showed the largest contractions in health spending as a percent of GDP. As shares of government expenditure, Thailand, Cambodia, the Republic of Korea, and Kiribati showed the highest growth in shares, while health seemed to be a diminishing priority of governments in Mongolia and Maldives (Figure 7).

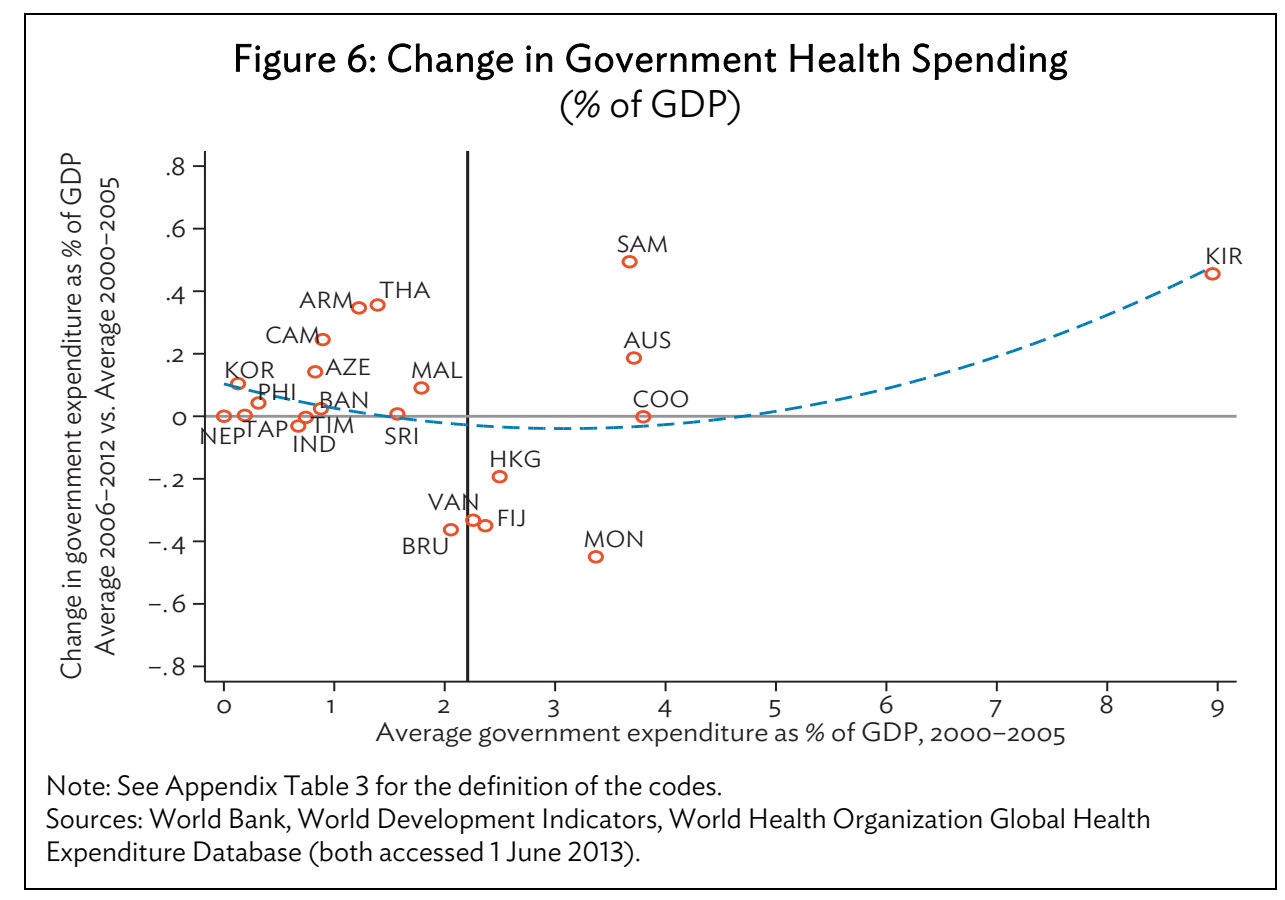




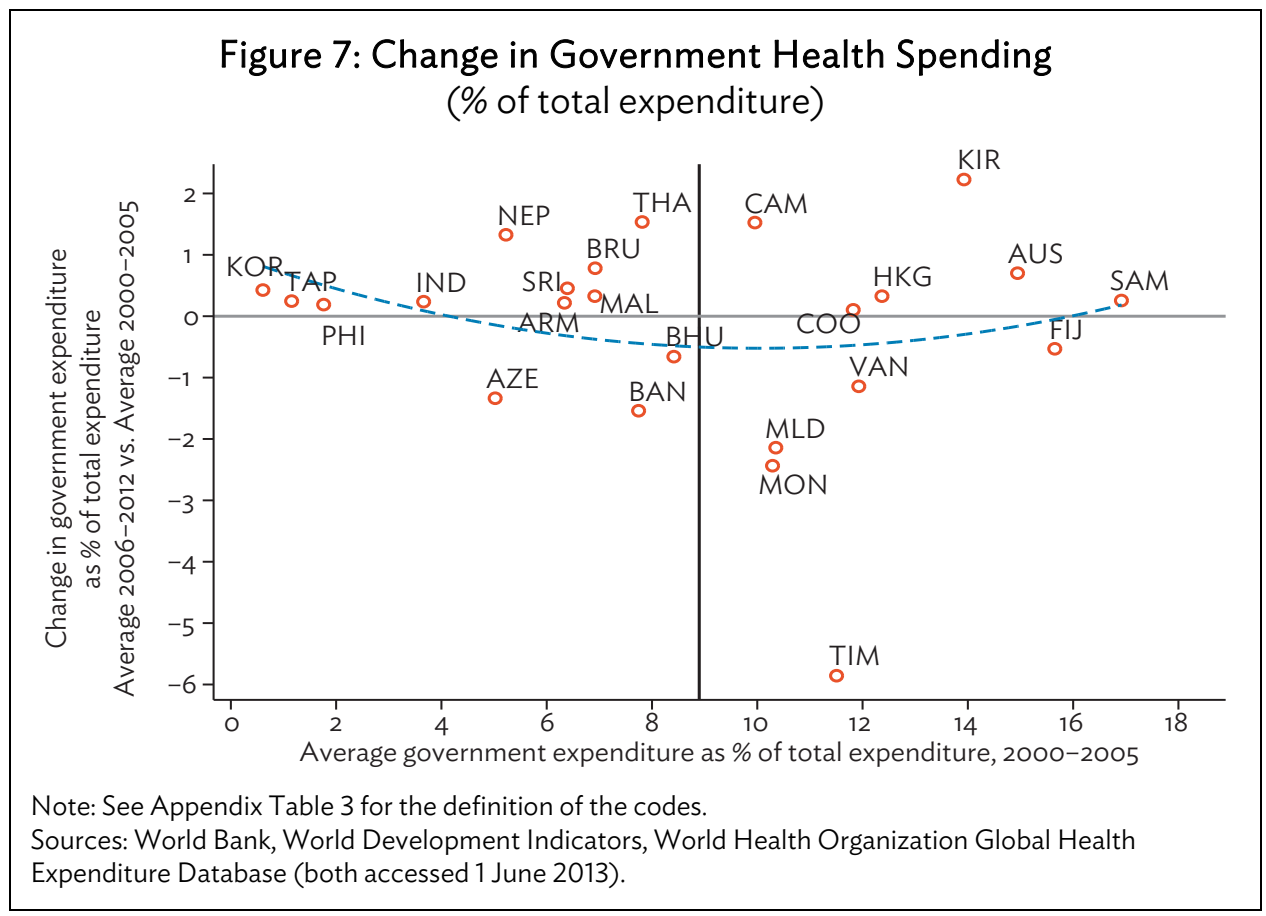

Government social protection spending ${ }^{2}$ showed very modest increases for most economies (Figures 8, 9). Except for Mongolia, most economies experienced only a slight increase in social protection spending during the last decade. Sri Lanka and Azerbaijan exhibited contractions in the share of social protection in their budget and as a percent of GDP.

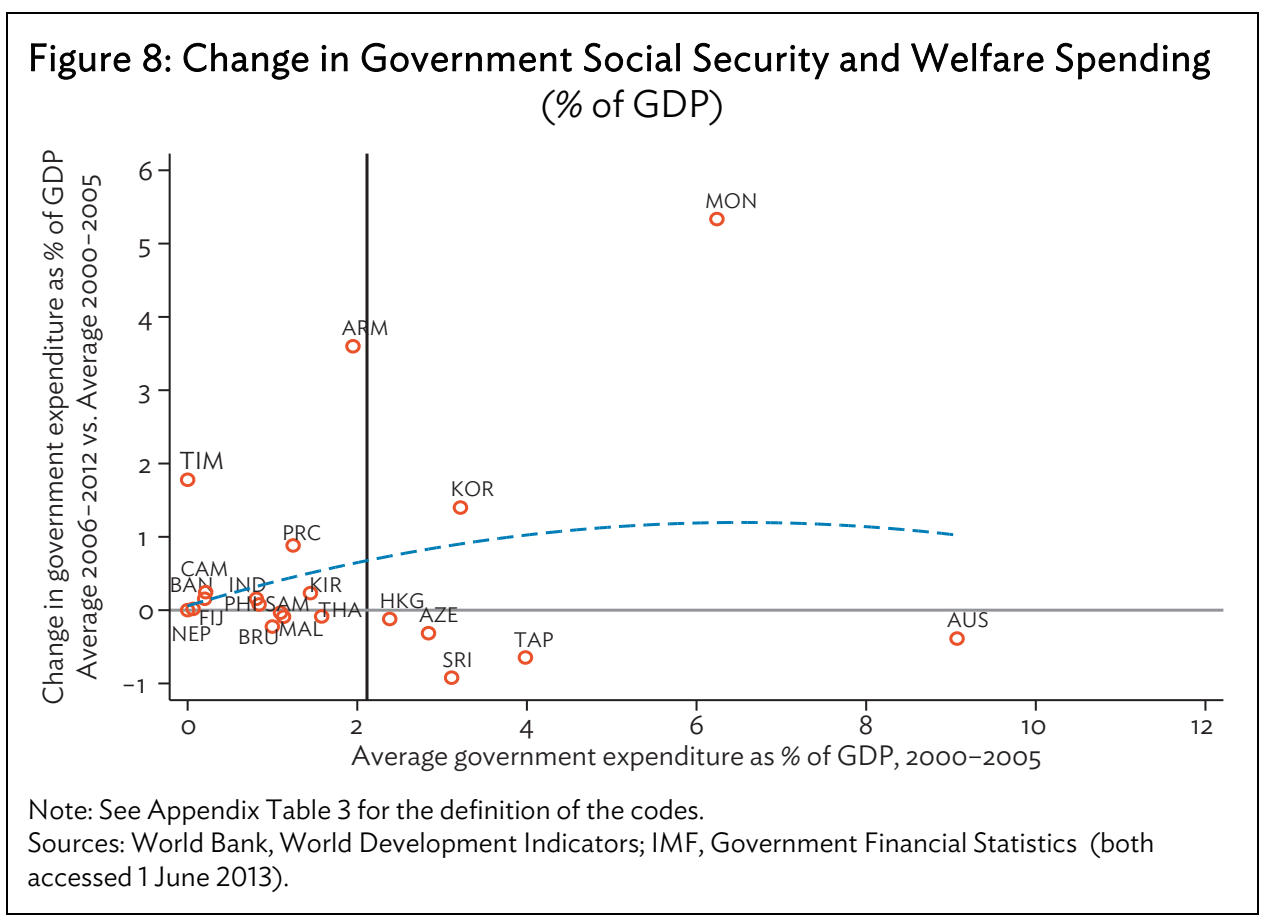

2 This includes only central government social protection expenditures. 


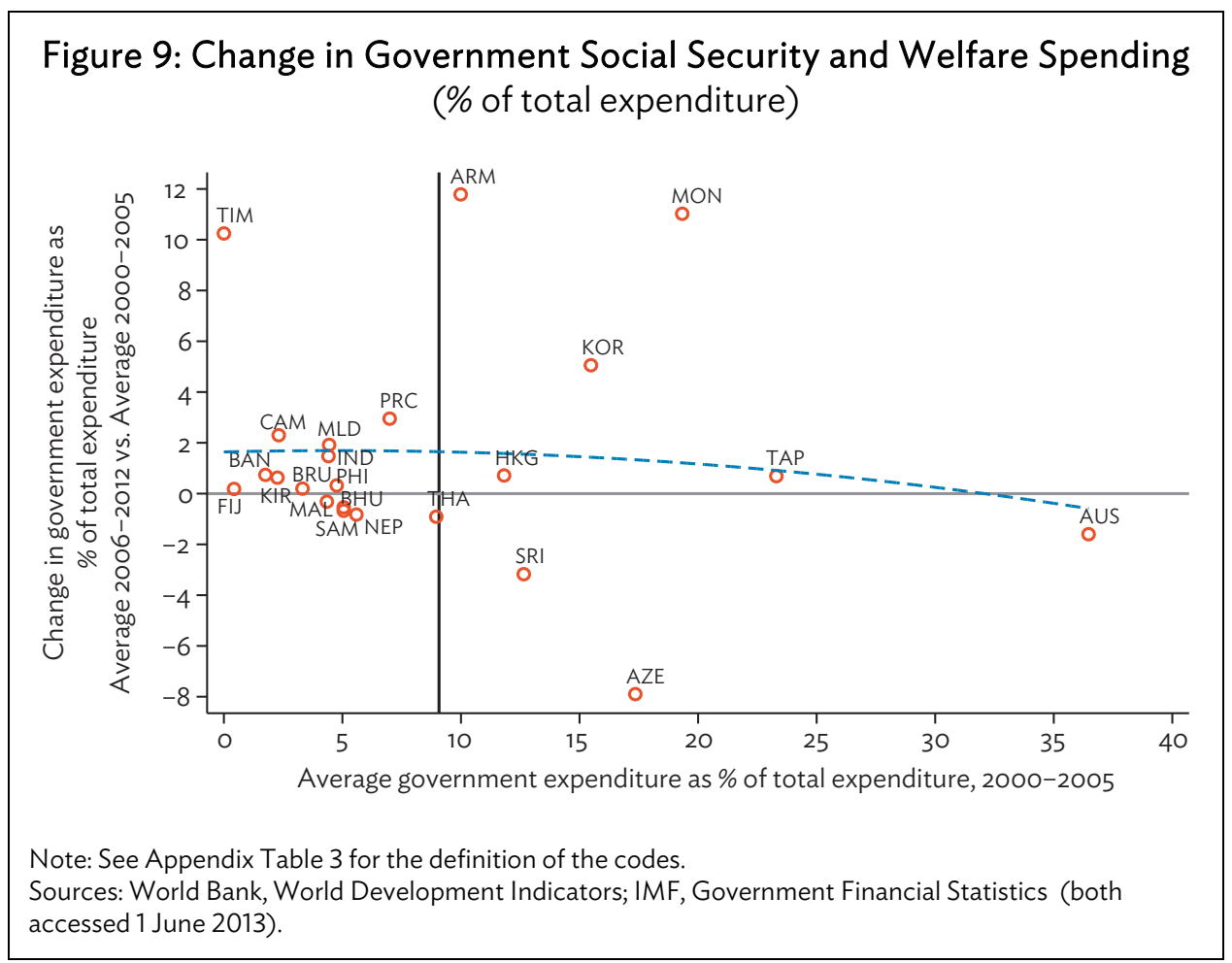

\section{EFFICIENCY OF PUBLIC EXPENDITURE}

There are a number of empirical benchmarking studies that focus on the efficiency of public expenditure on health and education. Most studies were concerned with expenditure efficiency (Herrera and Pang 2005) or technical efficiency using physical inputs (Afonso and St. Aubyn 2004). Hollingsworth (2003) wrote an exhaustive review about efficiency studies on health care. Thus, this section will focus only on recent empirical studies on both expenditure efficiency and technical efficiency. Most of the efficiency studies focused on the relative efficiency at the cross-country level, with very few conducting singlecountry analysis. An overview of selected studies is presented in Table 1.

\section{Expenditure Efficiency}

Gupta and Verhoeven (2001) examined the efficiency of government expenditure on health in 37 African countries from 1984 to 1995. Using free disposal hull (FDH), they calculated efficiencies of African countries relative to each other, and relative to other countries in Asia and the Western Hemisphere. Per capita education and health spending by the government in purchasing power parity (PPP) terms was taken as the input measure. Health output measures included life expectancy; infant mortality; and diphtheria, pertussis, and tetanus (DPT) and measles immunization rates. Education output measures were primary school enrollment, secondary school enrollment, and adult illiteracy. They found that there was a wide variation in the way government spending impacted on health and education outcome indicators. While government expenditure was associated with relatively high educational attainment for Zambia, Guinea, Ethiopia, and Lesotho, the same was not true for Botswana, Cameroon, Cote d' Ivoire, and Kenya. They also concluded that on the average, African countries were less efficient in providing health and education services compared to countries in Asia and the Western Hemisphere. 
De Sijpe and Rayp (2004) estimated government efficiency for 52 developing countries using Data Envelopment Analysis (DEA). Their input measure was central government expenditure per capita (in PPP). Outputs were infant mortality, immunization against measles, youth illiteracy rates, secondary enrollment, and government effectiveness. To allow for a lagged effect of public spending, they averaged expenditures over the period 1990-1994 and evaluated the outputs in the second half of the 1990s. Input efficiency score for the countries in the sample was on the average 0.50 implying that output indicators could be increased by $50 \%$, keeping inputs fixed. The People's Republic of China (PRC) and the Russian Federation were identified to be countries in the frontier, followed closely by Sri Lanka and Thailand. To explain efficiency scores, they also estimated a semi-log model, where efficiency score was the independent variable. Explanatory variables included GDP per capita, percent of population aged 0-14, private health expenditure per capita, urban population, perception of corruption, rule of law, political stability, voice and accountability measures, ethnic fractionalization, political rights, civil liberties, political constraints, dummy for armed conflict, Official Development Assistance (ODA) per capita, dummy for the International Monetary Fund (IMF) program, money and quasi money growth, liquid liabilities as percent of GDP, export of goods and services as percent of GDP, and foreign direct investment (FDI) inflows as percent of GDP. They concluded that efficiency was affected primarily by governance and political variables such as rule of law and political instability. Also, countries with high youth population, high adult illiteracy, and low private health spending found it difficult to register good health and education outcomes. Finally, economic variables, such as trade openness, FDI inflows, and ODA, did not seem to affect the efficiency of countries in providing services.

Afonso and St. Aubyn (2004) examined the efficiency of expenditures in the health and education sectors for a sample of OECD countries using FDH and DEA. They estimated efficiency frontiers using two kinds of inputs: (i) expenditure and (ii) quantifiable input measures such as instruction time in hours per year for 12-14 years old, number of teacher per student in public and private institutions for secondary education, inpatient beds, medical technology indicators, and health employment. Output for education was measured by the performance of 15-year-old students in reading, math, and science literacy scales in 2000, while infant mortality and life expectancy were used as health outputs. They found that in general, DEA and FDH results were not very different, with efficient countries in DEA being a subset of those identified as efficient under FDH. Another finding was that, efficiency attainments were different when the measurement of input was in terms of financial resources or physical inputs. For instance, among OECD countries, Sweden was efficient when inputs were measured in physical terms, but became inefficient when measured in expenditure terms due to relatively higher prices in the country. On the other hand, the Czech Republic and Poland were shown to be spending efficiently, but were not technically efficient. The reason cited was cheaper cost of labor in the two countries; thus, they became frontier countries when inputs were measured in financial terms.

Afonso, Schuknecht and Tanzi (2005) computed public sector performance and public sector efficiency indicators for 23 OECD countries using the FDH. Included in their indicators were secondary school enrollment and educational achievement for the education sector, and infant mortality and life expectancy for the health sector. The United States, Japan, and Luxembourg were identified as the most efficient countries in utilizing public expenditures in producing social services outcomes.

Using DEA and FDH in the first stage, Herrera and Pang (2005) examined the efficiency of public spending in providing social services among developing countries. The input was public 
expenditure on health and education. Output indicators for education were primary school enrollment, secondary school enrollment, first and second level completion rates, and learning scores. Health output indicators were life expectancy at birth, DPT and measles immunization rates, and disability-adjusted life expectancy (DALE). They used Tobit analysis in the second stage to explain variations in efficiency. Among the variables used in explaining efficiency scores were wages and salaries as percent of total public expenditure, total government expenditure as percent of GDP, share of publicly financed expenditure in health and education, constant GDP per capita, urban population, Gini coefficient, ODA as percent of fiscal revenue, and prevalence of AIDS. Their main conclusion was that countries found to be inefficient usually had higher expenditure levels and wage bills, higher ratios of public to private financing of services provision, and inequality levels as well as high aid dependency ratios.

Among the more popular application of parametric methodologies was the worldwide assessment of the effectiveness of health care delivery carried out by the World Health Organization (WHO) and presented in its World Health Report in 2000. Based on the study of Evans et al. (2000), the report presented a ranking of productive efficiencies of health care systems in 191 countries. Evans et al. (2000) used a fixed effects stochastic frontier methodology for a 5-year panel covering the period 1993-1997. Per capita public and private health expenditures and average years of education of the population were used as inputs, and two measures of health care attainment DALE and a composite measure of health care delivery were used as outputs. ${ }^{3}$ They found that Oman was the best performer in terms of DALE, while France performed best in health care delivery composite. Among their conclusions was that contrary to the popular belief that the PRC and Sri Lanka were efficient in providing health, they were in fact performing poorly compared to other developing countries. Poorest performers were those that had civil unrest during the study period and those with high AIDS prevalence.

The WHO report (2000), and subsequently the study of Evans et al. (2000), were met with many criticisms. One of the major criticisms was that the fixed effects model used did not capture the heterogeneity of the countries in the data. The wide variation in cultural and economic characteristics of the sample of countries produced a large amount of unmeasured heterogeneity in the data (Greene, 2003a). Hollingsworth and Wildman (2003) reestimated the rankings with DEA and Stochastic Frontier Analysis (SFA) using the same dataset. They noted that the WHO estimation procedure was too narrow so that contextual information was hidden by the use of only one method. The sample was also stratified by the OECD and non-OECD membership to determine the impact of more developed countries in the sample. They concluded that non-OECD countries showed more variation than OECD countries; therefore, it was important that the whole sample be divided into countries with similar characteristics.

Greene (2003a) also reestimated the study using the same dataset with recently developed alternatives to the SFA, which allowed for the incorporation of heterogeneity. He found that the results substantially differed with the WHO estimates when heterogeneity was taken into account. With DALE as an output, Japan was identified as the best performer rather than Oman, while Greece was identified as the best performer in health delivery composites instead of France. Such conflicting findings illustrate the difficulty of analyzing cross-country data.

\footnotetext{
Composite measure of health care delivery is a measure of success in five health goals: by year health, health distribution, responsiveness, responsiveness in distribution, and fairness in financing. This composite is an equally weighted composite of the five attainment variables. They were constructed from a survey data gathered by the WHO (Greene 2003a).
} 
One of the few studies that focused on an individual country was the study of Sampaio de Sousa and Stosic (2005) on Brazilian municipalities. Using DEA and FDH, they evaluated how public resources were utilized by local governments in a decentralized environment. Their input indicators were current spending, number of teachers, infant mortality rate, and hospital and health services. The output indicators were literate population, enrollment per school, student attendance per school, students who got promoted to the next grade per school, students in the right grade per school, and households with access to safe water, sewerage system, and garbage collection. Their main conclusion was that smaller municipalities tended to be less efficient than the larger ones.

Table 1: Overview of Previous Studies on Benchmarking in the Health and Education Sectors

\begin{tabular}{|c|c|c|c|c|}
\hline Author & Methodology & Outputs & Inputs & Environmental Variables \\
\hline $\begin{array}{l}\text { Gupta and } \\
\text { Verhoeven } \\
\text { (2001) }\end{array}$ & $\begin{array}{l}\text { FDH } \\
\text { Cross-country }\end{array}$ & $\begin{array}{l}\text { Life expectancy, infant } \\
\text { mortality, DPT and } \\
\text { measles immunization } \\
\text { rates, primary school } \\
\text { enrollment, secondary } \\
\text { school enrollment, adult } \\
\text { illiteracy }\end{array}$ & $\begin{array}{l}\text { Per capita education } \\
\text { and health spending } \\
\text { by the government } \\
\text { in PPP terms }\end{array}$ & \\
\hline $\begin{array}{l}\text { De Sijpe and } \\
\text { Rayp (2004) }\end{array}$ & $\begin{array}{l}\text { DEA } \\
\text { Cross-country }\end{array}$ & $\begin{array}{l}\text { Infant mortality, } \\
\text { immunization against } \\
\text { measles, youth illiteracy } \\
\text { rates, secondary } \\
\text { enrollment, government } \\
\text { effectiveness }\end{array}$ & $\begin{array}{l}\text { Central government } \\
\text { expenditure per } \\
\text { capita (in PPP) }\end{array}$ & $\begin{array}{l}\text { GDP per capita, percent of } \\
\text { population aged 0-14, } \\
\text { private health expenditure } \\
\text { per capita, urban } \\
\text { population, perception of } \\
\text { corruption, rule of law, } \\
\text { political stability, voice and } \\
\text { accountability measures, } \\
\text { ethnic fractionalization, } \\
\text { political rights, civil liberties, } \\
\text { political constraints, dummy } \\
\text { for armed conflict, ODA } \\
\text { per capita, dummy for IMF } \\
\text { program, money and quasi } \\
\text { money growth, liquid } \\
\text { liabilities as percent of GDP, } \\
\text { export of goods and services } \\
\text { as percent of GDP, FDI } \\
\text { inflows as percent of GDP }\end{array}$ \\
\hline $\begin{array}{l}\text { Afonso and St. } \\
\text { Aubyn (2004) }\end{array}$ & $\begin{array}{l}\text { DEA and FDH } \\
\text { Cross-country }\end{array}$ & $\begin{array}{l}\text { Performance of } 15 \text { years } \\
\text { old students on reading, } \\
\text { math, and science literacy } \\
\text { scales, infant mortality, } \\
\text { life expectancy }\end{array}$ & $\begin{array}{l}\text { Expenditure in } \\
\text { health and } \\
\text { education per capita, } \\
\text { instruction time in } \\
\text { hours per year for } \\
\text { 12-14 years old, } \\
\text { number of teacher } \\
\text { per student in public } \\
\text { and private } \\
\text { institutions for } \\
\text { secondary } \\
\text { education, inpatient } \\
\text { beds, medical } \\
\text { technology } \\
\text { indicators, } \\
\text { health employment }\end{array}$ & \\
\hline
\end{tabular}


Table 1 continued

\begin{tabular}{|c|c|c|c|c|}
\hline Author & Methodology & Outputs & Inputs & Environmental Variables \\
\hline $\begin{array}{l}\text { Afonso, } \\
\text { Schuknecht } \\
\text { and Tanzi } \\
\text { (2005) }\end{array}$ & $\begin{array}{l}\text { FDH } \\
\text { Cross-country }\end{array}$ & $\begin{array}{l}\text { Public sector } \\
\text { performance index }\end{array}$ & $\begin{array}{l}\text { Per capita } \\
\text { government } \\
\text { expenditure }\end{array}$ & \\
\hline $\begin{array}{l}\text { Herrera and } \\
\text { Pang (2005) }\end{array}$ & $\begin{array}{l}\text { DEA and FDH } \\
\text { Cross-country }\end{array}$ & $\begin{array}{l}\text { Primary school } \\
\text { enrollment, secondary } \\
\text { school enrollment, first } \\
\text { and second level } \\
\text { completion rate, learning } \\
\text { scores, life expectancy at } \\
\text { birth, DPT and measles } \\
\text { immunization rates, } \\
\text { disability-adjusted life } \\
\text { expectancy }\end{array}$ & $\begin{array}{l}\text { Public expenditure } \\
\text { on health and } \\
\text { education }\end{array}$ & $\begin{array}{l}\text { Wages and salaries as } \\
\text { percent of total public } \\
\text { expenditure, total } \\
\text { government expenditure as } \\
\text { percent of GDP, share of } \\
\text { publicly financed } \\
\text { expenditure in health and } \\
\text { education, constant GDP } \\
\text { per capita, urban } \\
\text { population, Gini coefficient, } \\
\text { ODA as percent of fiscal } \\
\text { revenue, prevalence of } \\
\text { AIDS }\end{array}$ \\
\hline $\begin{array}{l}\text { Evans, et al. } \\
(2000)\end{array}$ & $\begin{array}{l}\text { Fixed effects } \\
\text { Cross-country }\end{array}$ & $\begin{array}{l}\text { Disability adjusted life } \\
\text { expectancy, Health } \\
\text { delivery composite index }\end{array}$ & $\begin{array}{l}\text { Health expenditure, } \\
\text { average years of } \\
\text { education of the } \\
\text { population }\end{array}$ & \\
\hline $\begin{array}{l}\text { Hollingsworth } \\
\text { and Wildman } \\
\text { (2003) }\end{array}$ & $\begin{array}{l}\text { DEA and SFA } \\
\text { Cross-country }\end{array}$ & $\begin{array}{l}\text { Disability adjusted life } \\
\text { expectancy }\end{array}$ & $\begin{array}{l}\text { Health expenditure, } \\
\text { average years of } \\
\text { education of the } \\
\text { population }\end{array}$ & \\
\hline $\begin{array}{l}\text { Greene } \\
(2003 a)\end{array}$ & $\begin{array}{l}\text { DEA and SFA } \\
\text { Cross-country }\end{array}$ & $\begin{array}{l}\text { Disability adjusted life } \\
\text { expectancy, } \\
\text { Health delivery } \\
\text { composite index }\end{array}$ & $\begin{array}{l}\text { Health expenditure, } \\
\text { average years of } \\
\text { education of the } \\
\text { population }\end{array}$ & $\begin{array}{l}\text { Gini coefficient, measure of } \\
\text { democratization and } \\
\text { freedom of political unit, } \\
\text { measure of government } \\
\text { effectiveness, dummy for } \\
\text { tropical countries, } \\
\text { population density, GDP per } \\
\text { capita, dummy for OECD } \\
\text { membership }\end{array}$ \\
\hline $\begin{array}{l}\text { Sampaio de } \\
\text { Sousa and } \\
\text { Stosic (2005) }\end{array}$ & $\begin{array}{l}\text { DEA and SFA } \\
\text { Single country }\end{array}$ & $\begin{array}{l}\text { literate population, } \\
\text { enrollment per school, } \\
\text { student attendance per } \\
\text { school, students who get } \\
\text { promoted to the next } \\
\text { grade per school, } \\
\text { students in the right } \\
\text { grade per school, } \\
\text { households with access } \\
\text { to safe water, sewerage } \\
\text { system, and garbage } \\
\text { collection }\end{array}$ & $\begin{array}{l}\text { Current spending, } \\
\text { number of teachers, } \\
\text { infant mortality rate, } \\
\text { hospital and health } \\
\text { services }\end{array}$ & \\
\hline
\end{tabular}

$\mathrm{DEA}=$ Data Envelopment Analysis, DPT = diphtheria, pertussis, tetanus, $\mathrm{FDH}=$ free disposal hull, $\mathrm{FDI}=$ foreign direct investment, $\mathrm{GDP}=$ gross domestic product, IMF = International Monetary Fund, ODA = official development assistance, $\mathrm{OECD}=$ Organisation for Economic Co-Operation and Development, SFA = Stochastic Frontier Analysis.

Sources: Various papers cited in the reference list. 


\section{METHODS}

\section{A. Data Envelopment Analysis}

The most used nonparametric approach for benchmarking is the data envelopment analysis (DEA). Two decades after Farrell's (1957) proposal of a piecewise linear convex hull approach to frontier estimation, a study by Charnes, Cooper, and Rhodes (1978) found a method of estimation. DEA involves the use of linear programming techniques to determine which firms form an envelopment surface or efficient frontier. Firms are considered efficient if there are no other firms, or linear combination of firms, which produce more of at least one output (given the inputs) or use less of at least one input (given the outputs). The firms that lie on the surface are considered efficient, whereas the firms below the surface are termed inefficient, and their distance to the frontier provides a measure of their relative efficiency or inefficiency.

The Charnes, Cooper and Rhodes (1978) original specification of the ratio form of DEA was:

$$
\begin{gathered}
\max h_{0}=\frac{\sum_{r=1}^{s} u_{r} Y_{r 0}}{\sum_{i=1}^{m} v_{i} X_{i 0}} \\
\text { s.t. } \frac{\sum_{r=1}^{s} u_{r} Y_{r j}}{\sum_{i=1}^{m} v_{i} X_{i j}} \leq 1 ; j=1,2, \ldots \ldots, n \\
\frac{u_{r}}{\sum_{i=1}^{m} v_{i} X_{i 0}}>\varepsilon ; r=1,2, \ldots \ldots, s \\
\frac{v_{i}}{\sum_{i=1}^{m} v_{i} X_{i 0}}>\varepsilon ; i=1,2, \ldots \ldots ., m
\end{gathered}
$$

The relative performance of a unit (referred to as a decision making unit or DMU in DEA literature) was evaluated based on observed performance of other units $j=1,2, \ldots . n$.

Observed amounts of output and input were represented by $r$ and $j$, respectively. In the specification, $Y_{r j}, X_{i j}>0$ were constants representing outputs and inputs of the $j$ th firm which utilize these $i=1,2, \ldots . m$ inputs to produce $r=1,2, \ldots . . s$ outputs. The $u$ 's and $v$ 's are variables of the problem and were constrained to be greater than or equal to some small positive quantity $\varepsilon$ in order to avoid any input or output being ignored in computing the efficiency. The solution to the above model gave a value $h_{0}$, the efficiency of the unit being evaluated. If $h_{0}=1$, then the unit was efficient relative to the others. But if it was less than I then some other units were more efficient than this unit, which determines the most favorable set of weights. This flexibility was viewed as a weakness because even the judicious choice of weights by a unit, which is unrelated to the value of any input or output, may allow a unit to appear efficient. Another problem was, it has an infinite number of solutions, such that if $\left(u^{*}, v^{*}\right)$ was a solution, $\left(\xi u^{*}, \xi v^{*}\right)$ can also be a solution (Coelli 1996). 
To avoid both problems, the 1981 study of Charnes et al. imposed the constraint $v_{i} x_{i j o}=100 \%$ which led to the following specification:

$$
\begin{array}{lr}
\text { Max } h=\sum_{r} u_{r} y_{r y_{0}} & \\
\text { subject } \text { to } & \text { dual variable } \\
\sum_{i} v_{i} x_{i j_{0}}=100(\%) & Z_{0} \\
\sum_{r} u_{r} y_{r j}-\sum_{i} v_{i} x_{i j} \leq 0, \quad j=1, \cdots, n & \lambda_{j} \\
-v_{i} \leq-\varepsilon \quad i=1,2, \cdots, m & s_{i}^{+} \\
-u_{r} \leq-\varepsilon \quad r=1,2, \cdots, t & s_{r}^{-}
\end{array}
$$

Using the duality in linear programming, an equivalent envelopment form of this multiplier form was derived:

$$
\begin{aligned}
& \text { Min } 100 Z_{0}-\varepsilon \sum_{i} s_{i}^{+}-\varepsilon \sum_{r} s_{r}^{-} \\
& \text {subject to } \\
& \sum_{j} \lambda_{j} x_{i j}=x_{i j_{0}} Z_{0}-s_{i}^{+}, i=1, \cdots, m \\
& \sum_{j} \lambda_{j} y_{r j}=y_{r j_{0}}+s_{r}^{-}, r=1, \cdots, t \\
& \lambda_{j}, s_{i}^{+}, s_{r}^{-} \geq 0 .
\end{aligned}
$$

The dual variable $\lambda$ 's of the envelopment form were the shadow prices related to the constraints limiting the efficiency of each unit to be less than or equal to 1 . The value solved will be the efficiency score for the jth firm, with a value of 1, indicating a point on the frontier and therefore, a technically efficient firm, following Farrell's definition. The linear programming problem was solved $n$ times, once for each firm in the sample, and an efficiency value was obtained for each one. This envelopment form was specified as an input orientation which assumed constant returns to scale (CRS). ${ }^{4}$

The CRS assumption is appropriate only when all firms are operating at an optimal scale. Many factors, such as imperfect competition and financial constraints, however, may lead a firm not to operate on the optimal scale (Coelli 1996). In their 1984 paper, Banker, Charnes, and Cooper suggested an extension of the CRS-DEA model to account for situations with variable returns to scale (VRS). The specification was:

4 The envelopment form of the model is generally the preferred form to solve DEA. 


$$
\begin{aligned}
& \text { Max } h=\sum_{r} u_{r} y_{r j_{0}}-u_{0} \\
& \text { subject to } \\
& \sum_{i} v_{i} x_{i j_{0}}=100(\%) \\
& \sum_{r} u_{r} y_{r j}-\sum_{i} v_{i} x_{i j} \leq u_{0}, \quad j=1, \cdots, n \\
& -v_{i} \leq-\varepsilon \quad i=1, \cdots, m \\
& -u_{r} \leq-\varepsilon \quad r=1, \cdots, t
\end{aligned}
$$

The additional constraint imposed ensured that a firm was compared against other firms with similar size. The use of CRS-DEA even when firms were not operating on an efficient scale resulted in technical efficiency (TE) measures that included scale efficiencies (SE). The use of VRS-DEA allowed the separation of TE and SE.

Figure 10 below illustrates CRS and VRS concepts. The CRS frontier is the straight line OC with firm $\mathrm{F}$ being on the efficient frontier. The line VV is the VRS frontier which allows the optimal level of outputs and inputs to vary with the size of the firm in the sample. The decomposition of efficiency score into TE and SE is demonstrated using firm B. The firm's inefficiency, obtained from CRS-DEA, that is, the distance of $\mathrm{B}$ from the CRS model, is defined as $\frac{X J}{X B}$. A component of this ratio is scale inefficiency defined as $\frac{X J}{X L}$, the distance between CRS and VRS frontiers. After accounting for SE, pure TE is the point $\frac{X L}{X B}$.

\section{Figure 10: Constant Returns to Scale and Variable Returns to Scale Data Envelopment Analysis}

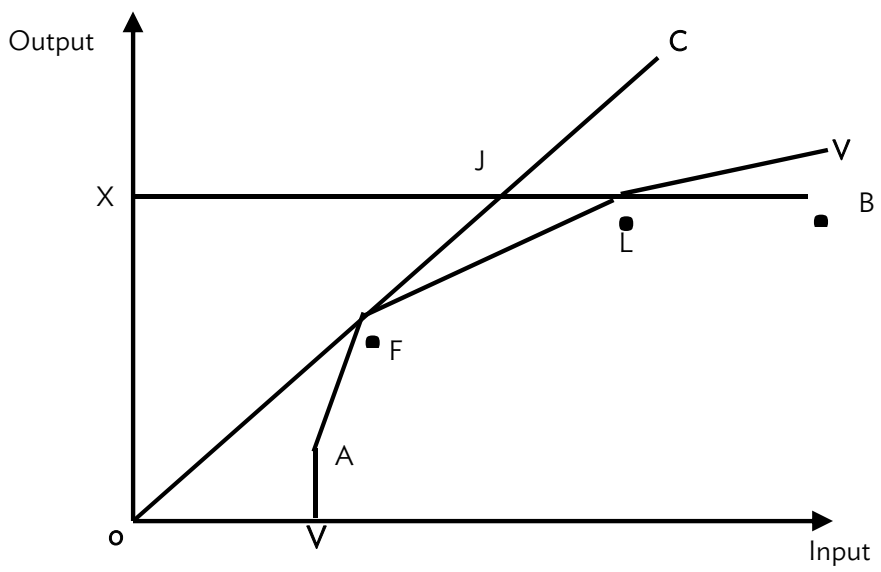

Source: Coelli 1996. 
The DEA approach will be illustrated using hypothetical data for provinces in Table 2 . The provinces in the sample have a medical staff ranging from 100 to 300 and barangay health stations (BHS) from 100 to 600 . The number of treated patients in 1 month ranges from 50 to 150 . To compare the five provinces, the inputs were translated into the number of treated mothers and children per input (represented by columns 4 and 5 in the table).

Table 2: Hypothetical Province Data

(unit)

\begin{tabular}{|c|c|c|c|c|c|}
\hline Province & $\begin{array}{c}\text { Doctors, } \\
\text { Nurses } \\
\text { and } \\
\text { Midwives }\end{array}$ & $\begin{array}{c}\text { Barangay } \\
\text { Health } \\
\text { Stations }\end{array}$ & $\begin{array}{c}\text { Treated } \\
\text { Patients }\end{array}$ & $\begin{array}{c}\text { Medical } \\
\text { Staff/Treated } \\
\text { Patients }\end{array}$ & $\begin{array}{c}\text { BHS/Treated } \\
\text { Patients }\end{array}$ \\
\hline 1 & 100 & 300 & 100 & 1 & 3 \\
\hline 2 & 300 & 600 & 150 & 2 & 4 \\
\hline 3 & 250 & 100 & 50 & 5 & 2 \\
\hline 4 & 300 & 150 & 100 & 3 & 1.5 \\
\hline 5 & 100 & 100 & 50 & 2 & 2 \\
\hline
\end{tabular}

BHS = barangay health station.

Source: Author's Statistics, adapted from Bhat, Verma, and Reuben 2001.

Given variations in inputs and outputs, it is difficult to facilitate comparison by numbers alone. The figure below (Figure 11) plots the data for medical staff and health stations per treated mothers and children. Provinces 1, 4, and 5, which are closest to the origin, are identified as the most efficient, meaning they are able to treat the most number of patients given the relatively smaller inputs. Provinces 2 and 3 are considered less efficient because, when compared to other provinces, they can still reduce their input use given their current output.

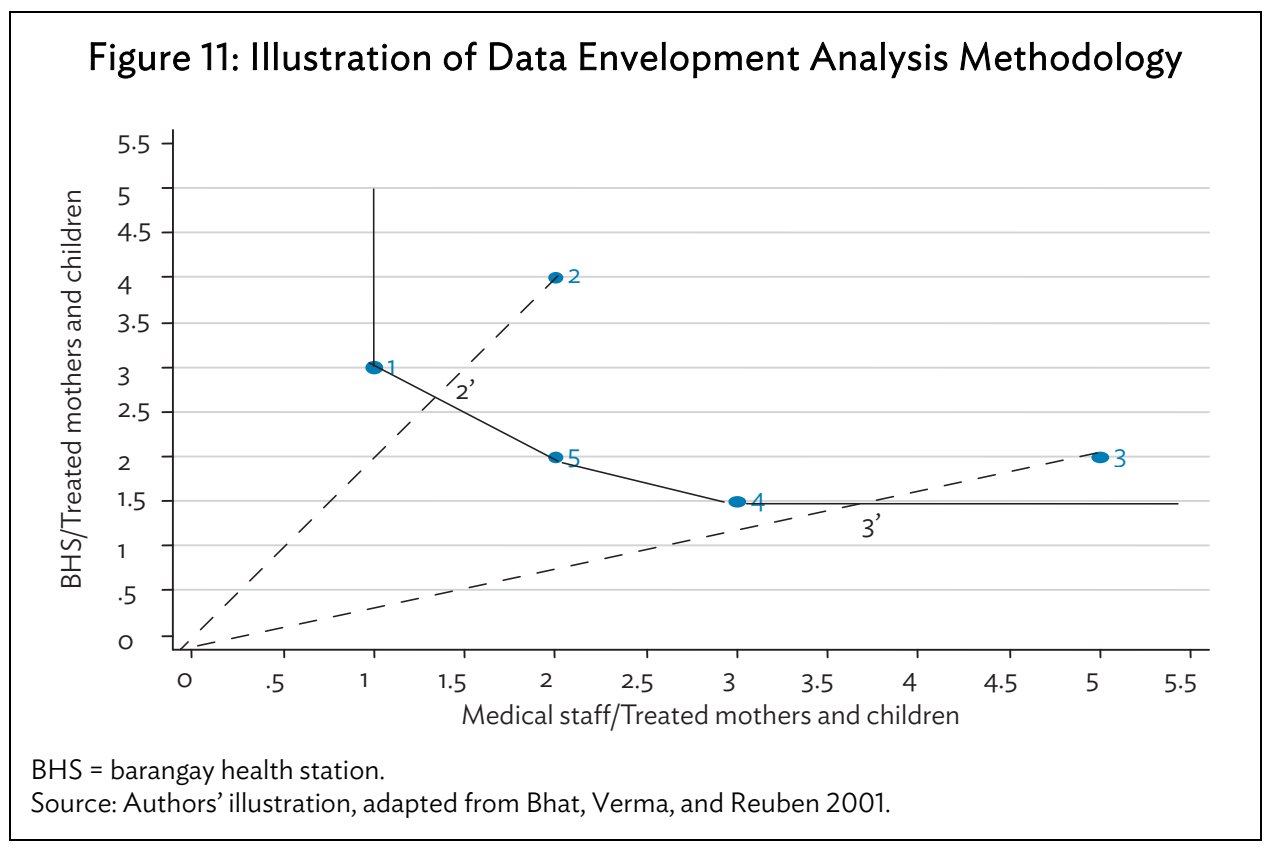


The TE score of province 2 is shown in the figure as line segment 2'2. Its numerical value is 0.67 , meaning the province could reduce its input usage by $33 \%$ and still treat 200 patients. If it were to operate at the hypothetical point 2', it needs to reduce its medical staff to 200 and its health stations to 400. Point 2' is derived from the combination of provinces 1 and 5, the provinces with the most similar production structure to province 2. Identification of these "peers" is one of the advantages of DEA for benchmarking purposes because it allows comparison of similar units.

Province 3 is another inefficient unit that needs to reduce its input usage. Province 4 has the most similar production characteristics to province 3 , among samples in the data. Province 3 has a TE score of 0.75 meaning its input use has to be reduced by one-fourth to reach the hypothetical point 3 '. Medical staff at point 3' is 187.5 and the number of health stations is 75 . However, point $3^{\prime}$ is not yet fully efficient because the number of medical staff can be reduced further similar to that of province 4 , while keeping the number of health stations constant. Thus, to fully maximize its efficiency, Province 3 has to reduce one of its inputs by more than one-fourth-medical staff has to be reduced further by 37.5 making it 150. This reduction is called input "slack" in DEA literature.

It is easy to illustrate and compute the methodology when the data structure is simple, in this case, two inputs and one output. In the presence of economies of scale and multiple outputs and inputs, the analysis becomes more complicated that it becomes necessary to use automated computer processes.

The illustration presented above depicts efficiency scores assuming CRS, implying that the size of the province is not relevant to its efficiency. This assumption might not be relevant to the health sector because of the presence of overheads. The VRS assumption of DEA allows the frontier to vary with the size of the units in the sample. This concept will be illustrated using a hypothetical data on rural health centers ( $\mathrm{RHCs}$ ) presented in Table 3.

\section{Table 3: Hypothetical Rural Health Centers Data} (unit)

\begin{tabular}{|c|c|c|}
\hline RHC & $\begin{array}{c}\text { Mothers Given } \\
\text { Prenatal Care }\end{array}$ & Medical Staff \\
\hline 1 & 10 & 2 \\
\hline 2 & 20 & 4 \\
\hline 3 & 30 & 3 \\
\hline 4 & 40 & 5 \\
\hline 5 & 50 & 6 \\
\hline
\end{tabular}

$\mathrm{RHC}=$ rural health center

Source: Authors' statistics.

Figure 12 below illustrates both CRS and VRS frontiers using one input and one output. The CRS frontier is represented by the line $O C$ which depicts the highest attainable output when the size of the health center is not considered. Line V'V is the VRS frontier. It passes through health centers 1, 3, and 5 , the units with the highest prenatal care to medical staff ratios, given adjustments in the size of health centers. The distance between the VRS and CRS frontiers represents the scale efficiency of each unit.

It should be noted that the CRS-TE can be obtained by multiplying the VRS-TE and the SE. It can be inferred that the CRS-TE is decomposed into pure TE (the VRS-TE) and SE. From Table 4, it 
can be seen that only health center 3 is efficient in either assumption, implying that it has the optimal scale among the samples. Health centers 1 and 5 are technically efficient, but are scale inefficient, with $\mathrm{RHC} 1$ operating under increasing returns to scale and RHC 5 operating under decreasing returns to scale. RHC numbers 2 and 4 are both technical and scale inefficient.

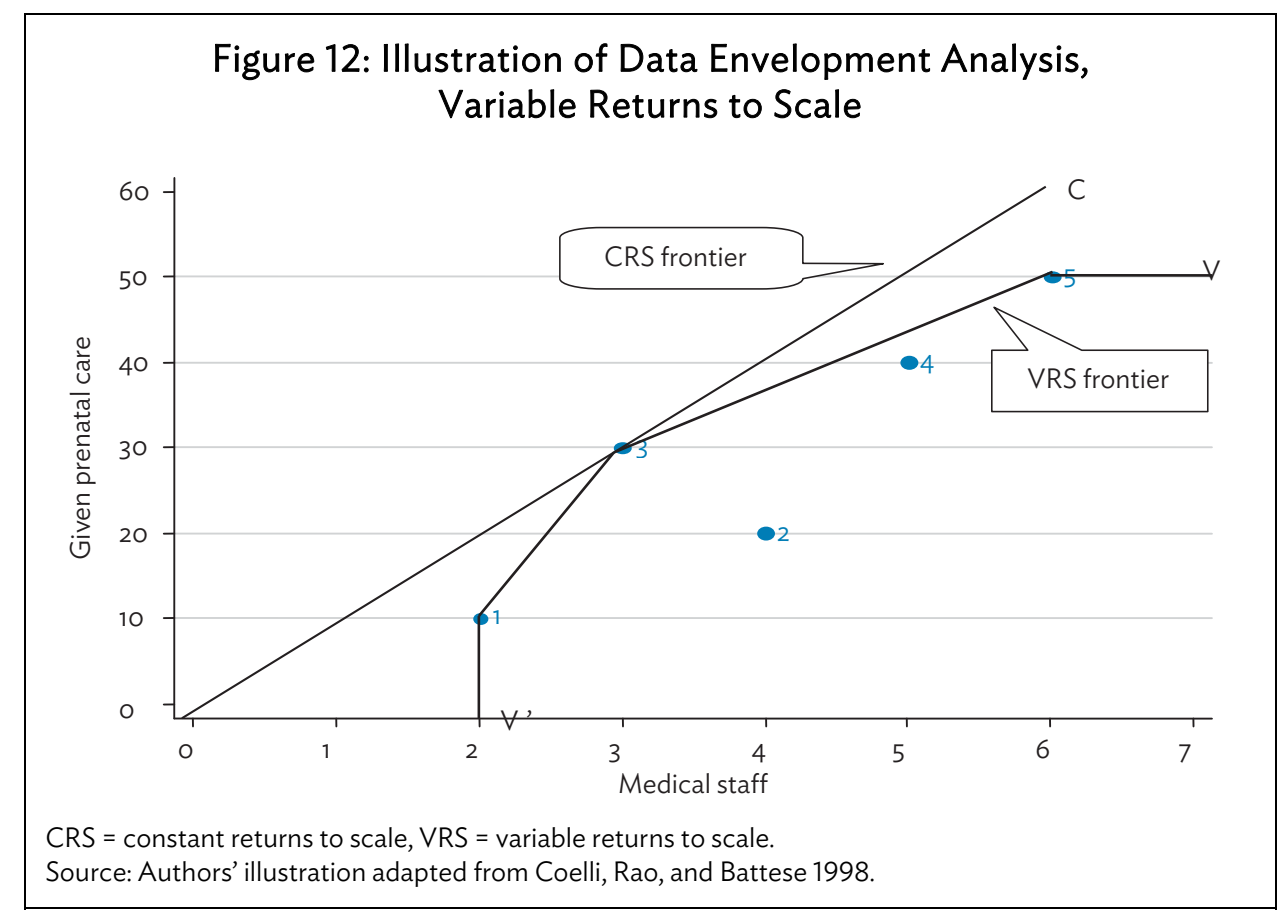

Table 4: Technical and Scale Efficiencies of Regional Health Center

\begin{tabular}{|r|c|c|c|c|}
\hline RHU & $\begin{array}{c}\text { Constant } \\
\text { Returns to } \\
\text { Scale-TE }\end{array}$ & $\begin{array}{c}\text { Variable } \\
\text { Returns to } \\
\text { Scale-TE }\end{array}$ & $\begin{array}{c}\text { Scale } \\
\text { Efficiency }\end{array}$ & Economies of Scale \\
\hline 1 & 0.500 & 1.000 & 0.500 & Increasing returns to scale \\
\hline 2 & 0.500 & 0.625 & 0.800 & Increasing returns to scale \\
\hline 3 & 1.000 & 1.000 & 1.000 & - \\
\hline 4 & 0.800 & 0.900 & 0.889 & Decreasing returns to scale \\
\hline 5 & 0.833 & 1.000 & 0.883 & Decreasing returns to scale \\
\hline
\end{tabular}

TE = technical efficiency.

Source: Author's calculations, adapted from Coellli, Rao, and Bettese 1998.

Increasing returns to scale implies the possibility for increasing size because when its inputs are doubled, the resulting output is more than doubled. Decreasing returns to scale, on the other hand, implies that the unit is operating above the optimal level-an increase of one input will lead to a less than one increase in output. This suggests that these units are potential candidates for downsizing.

DEA is also able to calculate both input efficiency scores and output efficiency scores. Input efficiency implies finding the least amount of input that can produce a given output level. Thus, when the major concern is to save cost, estimating input efficiency scores is a good choice. On the other hand, output efficiency means finding the highest possible output that can be attained without having to increase any of the inputs. 
Input and output efficiencies are illustrated in Figure 13 below using RHC 2 as an example. Assuming VRS, input efficiency of RHC 2 is represented by the ratio of distances $\frac{A B}{A 2}$. Output efficiency is given by the ratio $\frac{C 2}{C D}$.

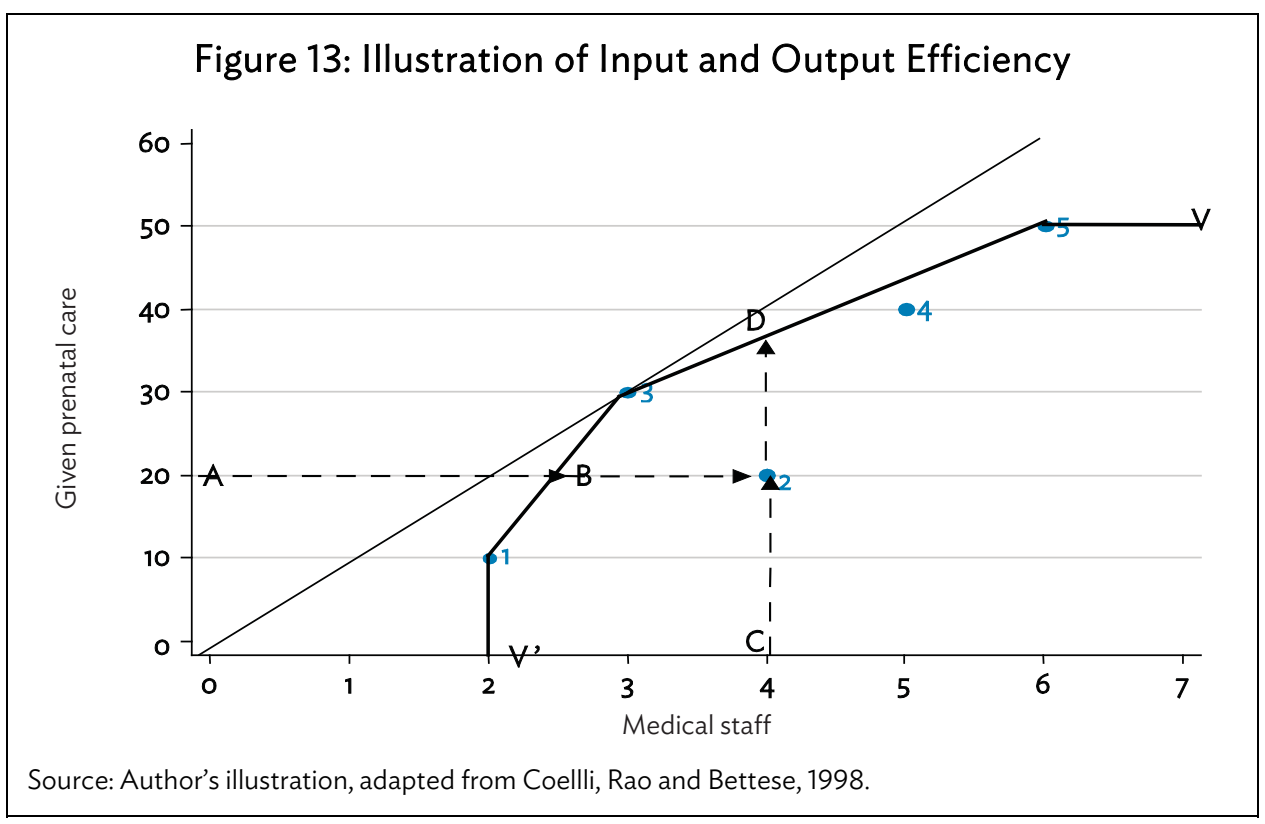

Units identified as efficient will remain as efficient regardless of the orientation chosen. For inefficient units, however, the TE values will be different. For instance, the input efficiency score of RHC 2 is 0.625 , while its output efficiency score is 0.545 . The input efficiency score implies that RHC can reduce its medical staff by $37 \%$ and still give prenatal care to its current level of 20 mothers. Output efficiency score means the number of mothers given prenatal care can still increase by $45 \%$ given its current medical staff of 4 .

The peers for RHC 2 are also different. Under input orientation, the peers of RHC 2 are health centers 1 and 3 , and under output orientation, they are 3 and 5 . Health center 3 , being a peer of both orientations implies that health centers 2 and 3 have very similar production compositions.

Fried, Lovell, and Schmidt (1993); Coelli, Rao, and Battese (1998); and Bhat, Verma, and Reuben (2001) provide a list of questions which DEA can help answer:

- How can appropriate models which will serve as benchmarks be selected?

- Which units are the most efficient?

- If all the units were to perform according to the best practice, how much more output could be produced and how much inputs could be reduced?

- What are the characteristics of the efficient units?

- What is the optimum scale of operations and how much can be saved if the units are operating at the optimal point?

- How can the differences in scale of operations be accounted for in performance benchmarking? 
By calculating the relative efficiencies of each unit, DEA is useful in identifying efficient units that will serve as models, which other units can follow. By providing input and output projections, policymakers can be guided as to what the appropriate targets are to improve performance.

Bowlin (2000) outlined the advantages and disadvantages of DEA. The advantage of DEA is that unlike traditional regression approaches, it does not require explicit specification of the functional forms relating inputs to outputs. More than one cost or production function is admitted, and the solution can be interpreted as providing a local approximation to whatever function is applicable based on outputs and inputs of the firms being evaluated. DEA is therefore more flexible in recognizing differences in production functions between firms. Second, DEA is oriented toward individual firms in which it conducts $n$ optimizations, one for each firm, in place of the single optimization that is usually associated with the regressions used in traditional efficiency analyses. Thus, the solution obtained from DEA is unique for each firm under evaluation. Third, a deficiency of all of the regression approaches is the inability to identify sources of inefficiency and to estimate the amounts of inefficiency associated with these sources. There is, therefore, no inference as to how corrective action will be provided even when the results show that inefficiencies are indeed present. DEA provides both the sources (input and output) and amounts of any inefficiency. Finally, DEA can also examine the effect of environmental variables which can further enhance the analysis when comparing heterogeneous firms (Yaisawarng and Klein 1994).

Among the drawbacks of DEA is that there is no consideration of random error or an " $\varepsilon$ " term in the model as there is in regression. Thus, DEA may tend to confuse random fluctuations with inefficiencies represented in the data, and the estimations lack statistical properties making hypothesis testing impossible. Also, since a subset of the available data defines the efficient frontier, while the rest of the observations have no impact on the shape of the envelopment surface, the results are very sensitive to measurement errors in the frontier firms. Further, the number of efficient firms on the frontier is sensitive to the number of inputs and outputs. As the ratio number of variables/sample size grows, the ability of DEA to discriminate among firms is sharply reduced, because it becomes more likely that a certain firm will find some set of weights to apply to its outputs and inputs, which will make it appear as efficient (Yunos and Hawdon 1997). For instance, a number of firms might be labeled $100 \%$ efficient not because they are really more efficient than other firms, but just because there are no other firms or combinations of firms against which they can be compared with when there are many dimensions of comparison.

DEA was chosen as the main methodology in this paper because based on previous studies, it is more suitable to the health sector compared to Stochastic Frontier Analysis (SFA). Many studies compared DEA and SFA using simulated data. Gong and Sickles (1992) found that SFA performs better than DEA when the technology and inefficiency distribution closely follow what was used in the data generating process. However, when the underlying technologies and efficiency distributions are unknown, DEA performs better than SFA. Even in the presence of heteroscedasticity, DEA-based estimators are bound to give better results (Banker, Chang, and Cooper 2004). According to Resti (2001), DEA also has a better performance when the dataset is composed of small samples.

\section{B. Malmquist Data Envelopment Analysis ${ }^{5}$}

With panel data, it is possible to run a variant of DEA which calculates Malmquist Total Factor Productivity (TFP) index to measure productivity change in order to provide information about how

5 This section is based on the discussion of Malmquist index in Coelli, Rao, and Battese (1998). 
the best practice frontier has moved over time. The Malmquist TFP index measures the TFP change between two data points by calculating the ratio of the distances of each data point relative to a common technology. The Malmquist (input oriented) TFP change index between period $s$ (the base period) and period $t$ is given by

$$
M_{i}\left(y_{s}, x_{s}, y_{t}, x_{t}\right)=\left[\frac{d_{i}^{s}\left(y_{t}, x_{t}\right)}{d_{i}^{s}\left(y_{s}, x_{s}\right)} \cdot \frac{d_{i}^{t}\left(y_{t}, x_{t}\right)}{d_{i}^{t}\left(y_{s}, x_{s}\right)}\right]^{\frac{1}{2}}
$$

where the notation $d_{i}^{s}\left(y_{t}, x_{t}\right)$ represents the distance from the period $t$ observation to the period $s$ technology. A value of $M_{i}$ greater than one will indicate positive TFP growth from period $s$ to period $t$ while a value less than one indicates a TFP decline. Equation (6) is the geometric mean of two TFP indices, with the first evaluated with respect to period $s$ technology, and the second with respect to period $t$ technology. This index can also be specified as:

$$
M_{i}\left(y_{s}, x_{s}, y_{t}, x_{t}\right)=\frac{d_{i}^{t}\left(y_{t}, x_{t}\right)}{d_{i}^{s}\left(y_{s}, x_{s}\right)}\left[\frac{d_{i}^{s}\left(y_{t}, x_{t}\right)}{d_{i}^{t}\left(y_{t}, x_{t}\right)} \cdot \frac{d_{i}^{s}\left(y_{s}, x_{s}\right)}{d_{i}^{t}\left(y_{s}, x_{s}\right)}\right]^{\frac{1}{2}}
$$

where the ratio outside the square brackets measures the change in the input-oriented measure of TE between periods $s$ and $t$. Thus, efficiency change is the ratio of the TE in period $t$ to the TE in period $s$. The ratios inside the brackets measure technical change or frontier shift, which captures the shifts in technology frontier. It is the geometric mean of the shift in technology between the two periods, evaluated at $x_{t}$ and also at $x_{s}$. To specify the decomposition,

$$
\begin{gathered}
\text { Efficiency change }=\frac{d_{i}^{t}\left(y_{t}, x_{t}\right)}{d_{i}^{s}\left(y_{s}, x_{s}\right)} \text { and } \\
\text { Technical change }=\left[\frac{d_{i}^{s}\left(y_{t} x_{t}\right)}{d_{i}^{t}\left(y_{t}, x_{t}\right)} \cdot \frac{d_{i}^{s}\left(y_{s}, x_{s}\right)}{d_{i}^{t}\left(y_{s}, x_{s}\right)}\right]^{\frac{1}{2}}
\end{gathered}
$$

\section{THE EFFICIENCY OF SOCIAL SERVICES EXPENDITURE IN ASIAN COUNTRIES}

Until a country reaches a level of social services provision that is accessible to everyone, the correlation between expenditures and outcomes is high. If there are major inequalities in income within the country, the poorer segment of the population can only rely on government facilities. Thus, when the government cuts its expenditure on health and education, the ones in great need are gravely affected.

This section attempts to measure the efficiency of Asian countries in utilizing public resources for health and education. A major problem in many countries is the allocation of scarce government resources to provide social services in the most efficient manner. The importance of examining public sector expenditure efficiency is particularly pronounced when countries are experiencing fiscal deficits. When services are publicly provided, performance measurement becomes an inevitable management tool. The government needs to identify poorly performing units since market mechanism cannot cut them out. When inefficiency continues, the constituents of that inefficient unit suffer. The 
government needs benchmarking tools to be able to provide incentives to induce these units to perform better.

\section{A. Data}

The input utilized is health and education expenditure per county. The outputs considered are health and education outcomes such as life expectancy, and DPT and measles immunization rates. Data for health is available for the period 1995-2010. For education, the outputs are the completion rates for primary, and secondary education (Table 5). Due to data availability issues in education completion data, we averaged years from 2006 to 2012 to perform the DEA.

Table 5: Input and Output Variables

\begin{tabular}{|l|l|}
\hline \multicolumn{1}{|c|}{ Input } & \multicolumn{1}{c|}{ Output } \\
\hline Health expenditure per capita & Life expectancy (years) \\
\hline & DPT immunization rate \\
\hline & Measles immunization rate \\
\hline Education expenditure per capita & Percentage of Completed Primary \\
\hline & $\begin{array}{l}\text { Percentage of Completed Lower } \\
\text { Secondary }\end{array}$ \\
\hline
\end{tabular}

DPT = diphtheria, pertussis, tetanus.

Sources: World Bank, World Development Indicators, World Health Organization, Global Health Expenditure Database (accessed 1 June 2013).

\section{B. Issues in the Estimation}

Comparison of countries suffers from factor heterogeneity problems. A main concern in this paper is that financially richer countries will have better outcomes. Tobit analysis on the efficiency scores will be conducted to see the effects of these variables.

When there is higher private expenditure on health and education in some countries, and the private sector provides better service, the efficiency score might be higher. As proxy for private expenditure, the percentages of private spending on health and education are included in the Tobit analysis.

Finally, as with most studies on health and education, the indicators used for outcomes or outputs might not necessarily reflect how healthy the people are or how much actual learning takes place in the country. It should be emphasized that it is not simple to identify the effects of public sector spending on outcomes accurately. It is difficult to assess to what extent higher life expectancy becomes a benchmark due to government intervention as opposed to other factors such as dietary habits and healthy lifestyle (Afonso, Schuknecht, and Tanzi 2005).

\section{Health and Education Efficiencies}

In 2010, Asian countries could use an average of $93 \%$ of their budget to attain the current level of health outcomes. In terms of output efficiency, an average score of $96 \%$ implies that with its current level of health per capita, the three outcome indicators can be increased further by $4 \%$ (Table 6 ). 
Table 6: Health Expenditure Efficiency Scores, 2010

\begin{tabular}{|l|c|c|}
\hline Country & Input Oriented & Output Oriented \\
\hline Afghanistan & 0.84 & 0.88 \\
\hline Armenia & 0.91 & 0.96 \\
\hline Azerbaijan & 0.86 & 0.95 \\
\hline Bangladesh & 0.94 & 0.96 \\
\hline Bhutan & 0.88 & 0.92 \\
\hline Brunei Darussalam & 1.00 & 1.00 \\
\hline Cambodia & 0.91 & 0.94 \\
\hline China, People's Republic of & 0.98 & 1.00 \\
\hline Fiji & 1.00 & 1.00 \\
\hline Georgia & 0.90 & 0.94 \\
\hline India & 0.78 & 0.87 \\
\hline Indonesia & 0.81 & 0.89 \\
\hline Kazakhstan & 1.00 & 1.00 \\
\hline Kiribati & 0.94 & 0.96 \\
\hline Korea, Republic of & 1.00 & 1.00 \\
\hline Kyrgyz Republic & 0.91 & 0.97 \\
\hline Lao People's Democratic & & \\
\hline Republic of & 0.94 & 0.96 \\
\hline Malaysia & 0.92 & 0.96 \\
\hline Maldives & 0.95 & 0.98 \\
\hline Marshall Islands & 0.92 & 0.96 \\
\hline Micronesia, Federated States of & 0.96 & 0.97 \\
\hline Mongolia & 0.93 & 0.97 \\
\hline Nepal & 0.83 & 0.90 \\
\hline Pakistan & 0.92 & 0.95 \\
\hline Palau & 1.00 & 1.00 \\
\hline Papua New Guinea & 0.95 & 0.87 \\
\hline Philippines & 0.88 & 0.93 \\
\hline Singapore & 1.00 & 1.00 \\
\hline Solomon Islands & 0.98 & 0.99 \\
\hline Sri Lanka & 1.00 & 1.00 \\
\hline Tajikistan & 0.91 & 0.94 \\
\hline Thailand & 1.00 & 1.00 \\
\hline Timor-Leste & 0.98 & 0.92 \\
\hline Tonga & 0.96 \\
\hline Turkmenistan & & \\
\hline Uzbekistan & 0.96 \\
\hline Vanuatu & 0.96 \\
\hline Viet Nam & 0.96 \\
\hline Average & 0.96 \\
\hline
\end{tabular}

Source: Authors' calculations 
Singapore, Fiji, Vanuatu, and Thailand dominate the DEA frontier for health expenditure estimation. On average, countries could have spent only $78 \%-98 \%$ of their budget to achieve current life expectancy, measles and DPT immunization rates. Average output efficiency score of 0.96 implies that with the same level of expenditure, health outcomes can be increased by $4 \%$ if all countries are expenditure efficient.

Countries like Brunei Darussalam, the Republic of Korea, Palau, and Sri Lanka are countries that were tagged as efficient only because they don't have peers in the group. The methodology is unable to pick up whether they are indeed efficient or just have different input and output structures compared to the rest. Appendix Table 1 contains the year-by-year DEA results in Health from 1995 to 2010, and Appendix Table 2 contains the list of peer economies.

For education, the DEA was performed using the average over 2006 to 2012 due to sparseness of data for education completion rates (Table 7). For the countries included in the analysis, inputoriented DEA says this set of countries overspend by $27 \%$ to achieve its average level of output over this time period. In terms of output, it can raise its output (here, a combination of primary and lower secondary school completion rates) by 6\%. The DEA method tagged Bangladesh, Nepal and Cambodia as efficient among its peers using the Input-oriented DEA but not in the output orientation. The output oriented method tagged Maldives and Samoa as efficient among its peers but not in the input method.

Table 7: Education Efficiency Scores, Average from 2006 to 2012

\begin{tabular}{|l|c|c|}
\hline & Input Oriented & Output Oriented \\
\hline Armenia & 0.47 & 0.93 \\
\hline Azerbaijan & 0.29 & 0.89 \\
\hline Bangladesh & 1.00 & 1.00 \\
\hline Brunei Darussalam & 1.00 & 1.00 \\
\hline Bhutan & 0.12 & 0.73 \\
\hline Fiji & 0.50 & 0.94 \\
\hline India & 1.00 & 1.00 \\
\hline Cambodia & 1.00 & 1.00 \\
\hline Sri Lanka & 1.00 & 1.00 \\
\hline Maldives & 1.00 & 1.00 \\
\hline Mongolia & 1.00 & 1.00 \\
\hline Nepal & 1.00 & 1.00 \\
\hline Philippines & 0.50 & 0.90 \\
\hline Vanuatu & 0.11 & 0.72 \\
\hline Samoa & 1.00 & 1.00 \\
\hline Average & 0.73 & 0.94 \\
\hline
\end{tabular}

Source: Authors' calculations. 
Table 8 below shows the most efficient and least efficient countries by outcome and by methodology. What drives these efficiency scores will be explored further in the Tobit analysis.

Table 8: Expenditure Efficiency in Asian Countries

\begin{tabular}{|l|l|l|}
\hline METHOD & \multicolumn{1}{|c|}{ MOST EFFICIENT } & \multicolumn{1}{c|}{ LEAST EFFICIENT } \\
\hline $\begin{array}{l}\text { Health } \\
\text { (DEA-input oriented) }\end{array}$ & $\begin{array}{l}\text { Fiji, Kazakhstan, Singapore, } \\
\text { Thailand, Vanuatu }\end{array}$ & $\begin{array}{l}\text { Afghanistan, Azerbaijan, } \\
\text { India, Indonesia, Nepal }\end{array}$ \\
\hline $\begin{array}{l}\text { Health } \\
\text { (DEA-output oriented) }\end{array}$ & $\begin{array}{l}\text { Fiji, Kazakhstan, Singapore, } \\
\text { Thailand, Vanuatu }\end{array}$ & $\begin{array}{l}\text { Afghanistan, India, Nepal, } \\
\text { Papua New Guinea }\end{array}$ \\
\hline $\begin{array}{l}\text { Education } \\
\text { (DEA-input oriented) }\end{array}$ & $\begin{array}{l}\text { Bangladesh, Cambodia, } \\
\text { India, Sri Lanka, Mongolia } \\
\text { Nepal }\end{array}$ & $\begin{array}{l}\text { Armenia, Azerbaijan, } \\
\text { Bhutan, Vanuatu }\end{array}$ \\
\hline $\begin{array}{l}\text { Education } \\
\text { (DEA-output oriented) }\end{array}$ & $\begin{array}{l}\text { India, Maldives, Mongolia, } \\
\text { Samoa, Sri Lanka }\end{array}$ & $\begin{array}{l}\text { Azerbaijan, Bhutan, } \\
\text { Philippines, Vanautu }\end{array}$ \\
\hline
\end{tabular}

DEA = Data Envelopment Analysis.

Source: Author's calculations.

\section{Efficiency Change over Time}

Health input efficiency scores are aggregated by region for the period 1995-2010 (Figure 14). The region with the highest input efficiency score is East Asia, followed by the Pacific, and Southeast Asia. South Asia and Central Asia are regions where the most input-inefficient countries are located.

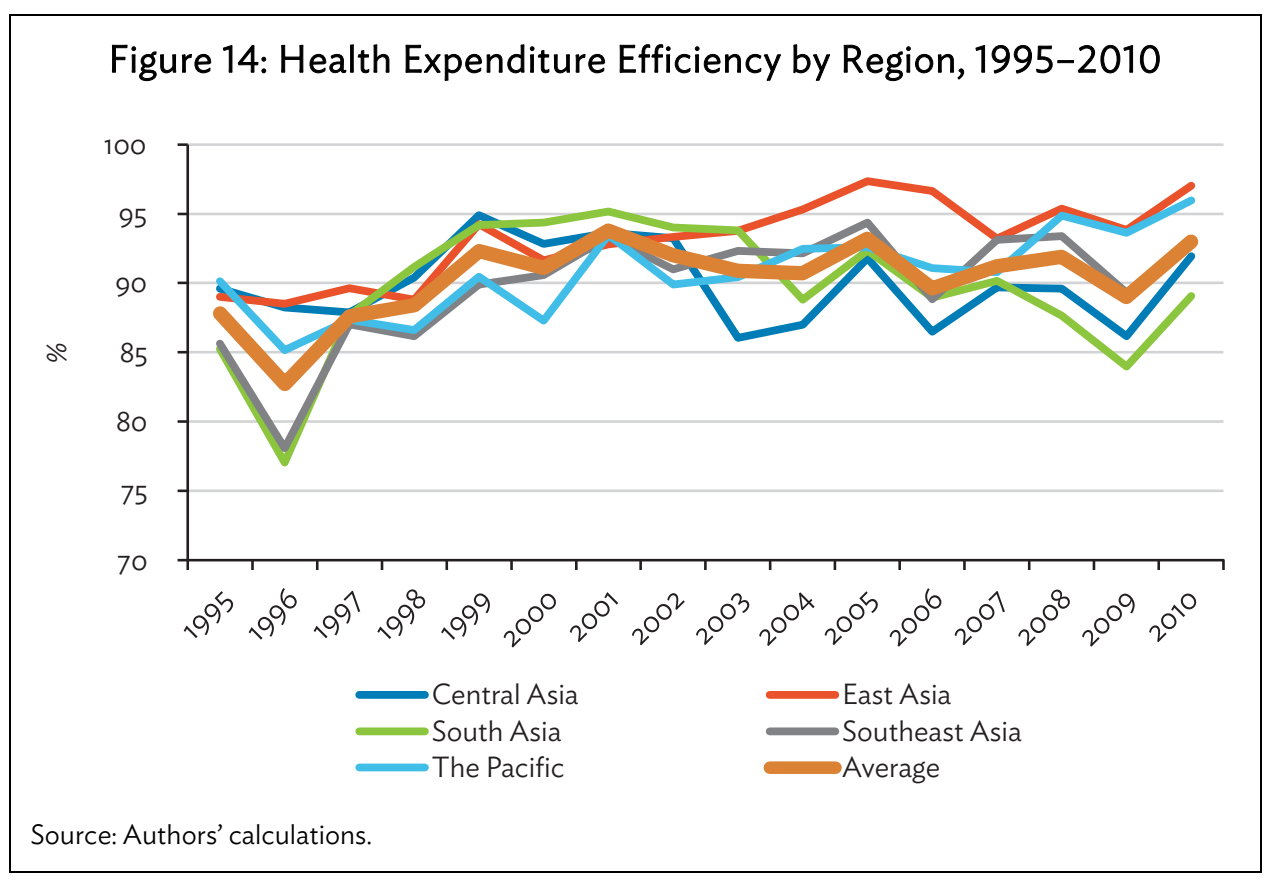

The Malmquist index makes it possible to distinguish whether the shift in frontier in different periods are due to changes in efficiency or changes in technology. The Malmquist TFP calculations are based on DEA-like linear programs, as described in the methodology section. The Malmquist TFP result for health expenditure is presented below (Table 9). 
The overall TE change (shown in column 2) represents changes in TE (position relative to the frontier), and this is made up of pure TE change (column 4) and SE change (column 5). The technical change index number (column 3) indicates how far the frontier against which TE is assessed has moved (frontier shift). Overall TFP growth (column 6) is a combination of TE change (column 2) and frontier shift or technical change (column 3).

The interpretation of the Malmquist index numbers presented in the Table 9 is explained using Afghanistan as an example. Afghanistan had a TFP growth of 1.2\% from 1995 to 2010 (represented by the index number in column 6 of 1.012). This is made up of an overall TE change of 1.003, and technical change of 1.01. The overall TE change can be further decomposed into a pure TE change of 0.988 and a SE change of 1.

Table 9: Productivity Change in Health for ADB Member Economies, 1995-2010

\begin{tabular}{|l|l|l|l|l|c|}
\hline Country & $\begin{array}{c}\text { Efficiency } \\
\text { Change }\end{array}$ & $\begin{array}{c}\text { Technology } \\
\text { Change }\end{array}$ & $\begin{array}{c}\text { Pure } \\
\text { Efficiency } \\
\text { Change }\end{array}$ & $\begin{array}{c}\text { Scale } \\
\text { Efficiency } \\
\text { Change }\end{array}$ & $\begin{array}{c}\text { Total } \\
\text { Factor } \\
\text { Productivity } \\
\text { Change }\end{array}$ \\
\hline Afghanistan & 1.003 & 1.010 & 0.988 & 1.014 & 1.012 \\
\hline Armenia & 1.005 & 0.991 & 0.997 & 1.007 & 0.996 \\
\hline Azerbaijan & 1.003 & 0.992 & 0.999 & 1.004 & 0.996 \\
\hline Bangladesh & 1.018 & 0.991 & 1.027 & 0.991 & 1.009 \\
\hline Bhutan & 1.004 & 0.991 & 1.001 & 1.003 & 0.995 \\
\hline Brunei Darussalam & 1.016 & 1.012 & 1.000 & 1.016 & 1.028 \\
\hline Cambodia & 1.009 & 1.004 & 1.020 & 0.989 & 1.013 \\
\hline China, People's Republic of & 1.008 & 0.992 & 1.015 & 0.993 & 1.000 \\
\hline Fiji & 1.009 & 0.996 & 1.003 & 1.006 & 1.005 \\
\hline Georgia & 0.989 & 0.992 & 0.993 & 0.996 & 0.981 \\
\hline India & 1.007 & 0.994 & 1.005 & 1.002 & 1.001 \\
\hline Indonesia & 0.997 & 0.992 & 1.000 & 0.997 & 0.989 \\
\hline Kazakhstan & 1.010 & 0.996 & 1.009 & 1.002 & 1.006 \\
\hline Kiribati & 0.987 & 0.997 & 0.999 & 0.989 & 0.984 \\
\hline Korea, Republic of & 1.018 & 1.009 & 1.000 & 1.018 & 1.027 \\
\hline Kyrgyz Republic & 1.009 & 0.992 & 1.004 & 1.005 & 1.001 \\
\hline Lao People's Democratic Republic & 1.023 & 0.995 & 1.027 & 0.996 & 1.018 \\
\hline Malaysia & 1.000 & 0.997 & 0.995 & 1.005 & 0.997 \\
\hline Maldives & 1.009 & 0.998 & 1.005 & 1.005 & 1.007 \\
\hline Marshall Islands & 0.988 & 1.003 & 0.995 & 0.993 & 0.991 \\
\hline Micronesia, Federated States of & 1.018 & 0.997 & 1.014 & 1.005 & 1.015 \\
\hline Mongolia & 1.005 & 0.992 & 1.003 & 1.002 & 0.997 \\
\hline Nepal & 0.998 & 0.993 & 1.006 & 0.992 & 0.991 \\
\hline Pakistan & 0.986 & 1.002 & 0.994 & 0.992 & 0.988 \\
\hline Palau & 1.001 & 1.016 & 1.000 & 1.001 & 1.018 \\
\hline & & & & & \\
\hline
\end{tabular}


Table 9 continued

\begin{tabular}{|l|c|c|c|c|c|}
\hline Country & Efficiency & Technology & $\begin{array}{c}\text { Pure } \\
\text { Change }\end{array}$ & $\begin{array}{c}\text { Scale } \\
\text { Change } \\
\text { Change }\end{array}$ & $\begin{array}{c}\text { Total } \\
\text { Factor } \\
\text { Change } \\
\text { Productivity } \\
\text { Change }\end{array}$ \\
\hline Papua New Guinea & 0.988 & 0.989 & 0.996 & 0.992 & 0.977 \\
\hline Philippines & 1.008 & 0.991 & 1.011 & 0.997 & 0.999 \\
\hline Singapore & 1.012 & 0.999 & 1.000 & 1.012 & 1.011 \\
\hline Solomon Islands & 1.017 & 0.991 & 1.019 & 0.998 & 1.008 \\
\hline Sri Lanka & 1.004 & 0.992 & 1.003 & 1.001 & 0.996 \\
\hline Tajikistan & 0.998 & 0.992 & 1.001 & 0.997 & 0.990 \\
\hline Thailand & 1.005 & 0.993 & 1.002 & 1.003 & 0.998 \\
\hline Timor-Leste & 1.015 & 0.996 & 1.010 & 1.005 & 1.010 \\
\hline Tonga & 1.007 & 0.996 & 1.004 & 1.003 & 1.003 \\
\hline Turkmenistan & 1.005 & 0.993 & 1.000 & 1.005 & 0.998 \\
\hline Uzbekistan & 1.012 & 0.992 & 1.011 & 1.001 & 1.004 \\
\hline Vanuatu & 1.013 & 0.998 & 1.006 & 1.007 & 1.011 \\
\hline Viet Nam & 1.006 & 0.992 & 1.001 & 1.005 & 0.998 \\
\hline Mean & 1.005 & 0.996 & 1.004 & 1.001 & 1.002 \\
\hline
\end{tabular}

Source: Authors' calculations.

On average, TFP increased by $0.2 \%$ from 1995 to 2000 . There was an improvement in TE of 0.5\%, implying that countries that were inefficient in 1995 had slightly better efficiency scores in 2010. The decrease in TFP is due to the low technology change score of 0.996 . This implies that the direction of frontier shift was inwards-countries in the frontier increased health expenditure levels but health outcome increases were slow. This also indicates that the efficiency improvements at the frontier were much slower than the rate of improvement in less efficient countries.

For education, the Malmquist index was calculated using two time periods averaging educational completion rates from 1990 to 2005, and 2006 to 2012. This averaging was necessary to maximize the number of countries included in the benchmarking exercise. In Table 10, total factor productivity fell by almost an average of $50 \%$ over these two time periods. There are differences across countries - some countries exhibited efficiency increases over time and others didn't. The reason why TFP fell for all countries is that Technology change is negative (shift inward of the frontier) and overwhelmed even those countries who posted efficiency gains. This is reflected in the raw data. Public education budgets grew significantly during the period, while improvements in primary completion and lower secondary levels are small or nonexistent.

Performance is varied among countries. Among the countries in the frontier, Singapore and Vanuatu had an increase in TFP of 1.1\% from 1995 to 2010. Afghanistan was identified as one of the most input inefficient in 2010. Table 11 shows, however, that from 1995 to 2010 Afghanistan increased its life expectancy by 4 years, its DPT immunization rates by 46 percentage points, and its measles immunization rate by 21 percentage points, despite a relatively modest government health expenditure per capita increase. This is in contrast with other inefficient countries in 1995 such as India, Indonesia, 
Nepal, and Azerbaijan. Their health budgets increased but this relative increase in outcomes in the past 15 years has been slow.

Table 10: Productivity Change in Education for ADB Member Economies, 1995-2010

\begin{tabular}{|l|l|l|l|c|c|}
\hline & $\begin{array}{c}\text { Efficiency } \\
\text { Change }\end{array}$ & $\begin{array}{c}\text { Technology } \\
\text { Change }\end{array}$ & $\begin{array}{c}\text { Pure } \\
\text { Efficiency } \\
\text { Change }\end{array}$ & $\begin{array}{c}\text { Scale } \\
\text { Efficiency } \\
\text { Change }\end{array}$ & $\begin{array}{c}\text { Total Factor } \\
\text { Productivity } \\
\text { Change }\end{array}$ \\
\hline Armenia & 0.362 & 0.593 & 0.931 & 0.389 & 0.215 \\
\hline Azerbaijan & 0.292 & 0.593 & 0.948 & 0.308 & 0.173 \\
\hline Bangladesh & 1.079 & 0.593 & 1 & 1.079 & 0.64 \\
\hline Brunei Darussalam & 1.635 & 0.574 & 1.37 & 1.193 & 0.939 \\
\hline Bhutan & 1.606 & 0.571 & 1.87 & 0.859 & 0.916 \\
\hline Cambodia & 1.193 & 0.593 & 1.016 & 1.175 & 0.708 \\
\hline Fiji & 1.329 & 0.574 & 1.246 & 1.066 & 0.763 \\
\hline India & 1 & 0.582 & 1 & 1 & 0.582 \\
\hline Maldives & 0.888 & 0.588 & 1 & 0.888 & 0.523 \\
\hline Mongolia & 0.55 & 0.574 & 1 & 0.55 & 0.316 \\
\hline Nepal & 0.749 & 0.593 & 1.208 & 0.62 & 0.444 \\
\hline Philippines & 0.798 & 0.568 & 1 & 0.798 & 0.453 \\
\hline Samoa & 1.036 & 0.588 & 1.043 & 0.993 & 0.609 \\
\hline Sri Lanka & 1.064 & 0.581 & 1.06 & 1.003 & 0.618 \\
\hline Vanuatu & 0.722 & 0.593 & 1 & 0.722 & 0.428 \\
\hline Average & 0.863 & 0.584 & 1.094 & 0.79 & 0.504 \\
\hline
\end{tabular}

Table 11: Government Health Expenditure, Outputs, and Productivity Change for Efficient and Inefficient Economies

\begin{tabular}{|c|c|c|c|c|c|c|}
\hline & Year & $\begin{array}{c}\text { Life } \\
\text { Expectancy }\end{array}$ & $\begin{array}{c}\text { DPT } \\
\text { Immunization } \\
\text { Rate }\end{array}$ & $\begin{array}{c}\text { DPT } \\
\text { Immunization } \\
\text { Rate }\end{array}$ & $\begin{array}{l}\text { Government } \\
\text { Health Exp. } \\
\text { Per capita } \\
\text { (USD) }\end{array}$ & $\begin{array}{c}\text { TFP } \\
\text { Change }\end{array}$ \\
\hline \multicolumn{7}{|c|}{ Frontier Countries } \\
\hline Singapore & 1995 & 76.39 & 98 & 97 & 367.69 & \multirow{2}{*}{1.011} \\
\hline Singapore & 2010 & 81.64 & 97 & 95 & 629.10 & \\
\hline Vanuatu & 1995 & 65.46 & 73 & 60 & 31.70 & \multirow{2}{*}{1.011} \\
\hline Vanuatu & 2010 & 70.82 & 68 & 52 & 142.56 & \\
\hline Fiji & 1995 & 66.64 & 97 & 94 & 62.53 & \multirow{2}{*}{1.005} \\
\hline Fiji & 2010 & 69.23 & 99 & 94 & 108.19 & \\
\hline Thailand & 1995 & 72.26 & 96 & 91 & 46.76 & \multirow[b]{2}{*}{0.998} \\
\hline Thailand & 2010 & 73.93 & 99 & 98 & 134.43 & \\
\hline \multicolumn{7}{|c|}{ Inefficient Countries } \\
\hline India & 1995 & 59.83 & 71 & 72 & 4.10 & \multirow{2}{*}{1.001} \\
\hline India & 2010 & 65.13 & 72 & 74 & 15.82 & \\
\hline Indonesia & 1995 & 63.98 & 69 & 63 & 7.07 & \multirow{2}{*}{0.989} \\
\hline Indonesia & 2010 & 68.89 & 83 & 89 & 37.74 & \\
\hline
\end{tabular}


Table 11 continued

\begin{tabular}{|c|c|c|c|c|c|c|}
\hline & Year & $\begin{array}{c}\text { Life } \\
\text { Expectancy }\end{array}$ & $\begin{array}{c}\text { DPT } \\
\text { Immunization } \\
\text { Rate }\end{array}$ & $\begin{array}{c}\text { DPT } \\
\text { Immunization } \\
\text { Rate }\end{array}$ & $\begin{array}{l}\text { Government } \\
\text { Health Exp. } \\
\text { Per capita } \\
\text { (USD) }\end{array}$ & $\begin{array}{c}\text { TFP } \\
\text { Change }\end{array}$ \\
\hline \multicolumn{7}{|c|}{ Inefficient Countries } \\
\hline Nepal & 1995 & 57.47 & 54 & 56 & 1.60 & \multirow{2}{*}{0.991} \\
\hline Nepal & 2010 & 68.39 & 82 & 86 & 9.90 & \\
\hline Afghanistan & 1995 & 43.84 & 20 & 41 & 0.83 & \multirow{2}{*}{1.012} \\
\hline Afghanistan & 2010 & 48.28 & 66 & 62 & 4.39 & \\
\hline Azerbaijan & 1995 & 64.58 & 74 & 64 & 4.33 & \multirow{2}{*}{0.996} \\
\hline Azerbaijan & 2010 & 70.51 & 72 & 67 & 67.26 & \\
\hline
\end{tabular}

DPT = diphtheria, pertussis, tetanus; TFP = total factor productivity.

Source: Authors' calculations.

Looking at education's productivity change in Table 12, we find TFP decreases in spending by both frontier and inefficient countries alike. The smallest decrease is Bhutan, which was found to be input and output inefficient. Compared to other countries, including the frontier countries, Bhutan increased its primary and lower secondary completion rates by a significant margin (48\% to $85 \%$ and $20 \%$ to $50 \%$, respectively) compared to other countries in the table. Indeed, Vanuatu's primary completion rate fell, while its spending on education almost doubled (\$68 to \$103 per capita).

\section{Table 12: Government Education Expenditure, Outputs, and Productivity Change for Efficient and Inefficient Economies}

\begin{tabular}{|c|c|c|c|c|c|}
\hline Economy & Time Periods & $\begin{array}{c}\text { Primary } \\
\text { Completion Rate }\end{array}$ & $\begin{array}{c}\text { Lower } \\
\text { Secondary } \\
\text { Completion } \\
\text { Rate } \\
\end{array}$ & $\begin{array}{c}\text { Government } \\
\text { Education Exp. } \\
\text { per capita, } \\
\text { (USD) }\end{array}$ & $\begin{array}{c}\text { TFP } \\
\text { Change }\end{array}$ \\
\hline \multicolumn{6}{|l|}{ Frontier Countries } \\
\hline India & 1990-2005 & 74.9 & 55.9 & 16.01 & \multirow{2}{*}{0.582} \\
\hline India & 2006-2012 & 98.1 & 71.0 & 26.75 & \\
\hline Sri Lanka & 1990-2005 & 101.8 & 79.2 & 19.86 & \multirow{2}{*}{0.618} \\
\hline Sri Lanka & 2006-2012 & 96.3 & 95.5 & 45.42 & \\
\hline Mongolia & 1990-2005 & 89.1 & 74.9 & 37.54 & \multirow{2}{*}{0.316} \\
\hline Mongolia & 2006-2012 & 116.9 & 96.7 & 109.12 & \\
\hline \multicolumn{6}{|l|}{ Inefficient Countries } \\
\hline Vanuatu & 1990-2005 & 90.3 & 30.6 & 68.66 & \multirow{2}{*}{0.428} \\
\hline Vanuatu & $2006-2012$ & 83.2 & 41.2 & 103.37 & \\
\hline Bhutan & 1990-2005 & 48.0 & 20.8 & 52.54 & \multirow{2}{*}{0.916} \\
\hline Bhutan & 2006-2012 & 85.6 & 58.1 & 125.24 & \\
\hline Azerbaijan & 1990-2005 & 92.9 & 80.5 & 21.51 & \multirow{2}{*}{0.173} \\
\hline Azerbaijan & 2006-2012 & 92.4 & 90.2 & 139.18 & \\
\hline
\end{tabular}

TFP = total factor productivity.

Source: Authors' calculations.

This illustrates the usefulness of the Malmquist index in efficiency benchmarking. By comparing productivity changes in two or more periods, the real efficient and inefficient countries can be identified. 


\section{E. Explaining Efficiency Scores}

This section aims to seek factors that will explain differences in efficiency scores among countries. By using regression techniques, this section identifies statistical association between efficiency scores and environmental variables. Environmental variables are factors that are not included in the efficiency estimation but might influence efficiency scores. Among the environmental variables that are used as regressors are GDP per capita, percent of total health expenditure coming from external funds, and percent of paved roads.

A major concern in this kind of analysis is the correlation between the input variables used in the DEA estimation and the environmental variables used in the regression analysis. When the variables are highly correlated, the coefficients will be inconsistent and biased (Herrera and Pang 2005, Ravallion 2003, Grosskopf 1996). Table 13 shows, with the exception of GDP per capita, there is no high correlation between input variables and environmental variables, making them suitable for regression analysis. Efforts will be made in future drafts to look for proxy variables for GDP and to find other explanatory variables for the analysis.

Table 13: Correlation Coefficients of Independent Variables

\begin{tabular}{|l|c|c|c|c|}
\hline & Expenditure & GDP per capita & $\begin{array}{c}\text { \% of external } \\
\text { assistance in health }\end{array}$ & \% road paved \\
\hline Health expenditure & 1.0000 & & & \\
\hline GDP per capita & 0.8611 & 1.0000 & & \\
\hline \% of external assistance in health & -0.0578 & -0.1778 & 1.0000 & \\
\hline \% road paved & 0.3924 & 0.4695 & -0.4129 & 1.0000 \\
\hline
\end{tabular}

GDP = gross domestic product.

Source: Authors' calculations.

\section{F. Method}

The Tobit model was used in the regression because of the censored nature of efficiency scores. According to Maddala (1987) and Greene (2003b), the fixed effects estimator for a panel data with short periods will have inconsistent coefficients and biased variance. Thus, random effects Tobit estimation was chosen. The Tobit estimation is as follows:

$$
\text { Efficiency }_{i t}=f\left(g d p_{i t}, \text { ext }_{i t} \text { roads }_{i t}\right)
$$

where Efficiency $_{i t}=$ health input efficiency scores from VRS-DEA

$g d p_{i t}=$ GDP per capita

ext $_{i t}=\%$ of total health expenditure from external donors

roads $_{i t}=\%$ of roads paved

\section{G. Estimation Results}

The result of the Tobit regression for factors explaining efficiency scores are presented below (Table 14). In general, GDP and higher percentage of paved roads increase efficiency, while the effect of external aid is unclear. 


\section{Table 14: Regression Results: Factors Affecting Expenditure Efficiency Scores}

\begin{tabular}{lr}
\hline Independent Variable & Efficiency \\
\hline GDP per capita (In) & $.0138421^{*}$ \\
& $(.0087)$ \\
\% of total health expenditure from external aid & .0002105 \\
& $(.0005891)$ \\
\% of paved roads & $.0010408^{* * *}$ \\
Observations & $(.0003408)$ \\
Number of countries & 221 \\
Wald Chi2 & 33 \\
(Prob>Chi2) & 18.71 \\
\hline Notes: Absolute value of z-statistics in parentheses, ${ }^{*}=$ significant at 10\% ${ }^{* *}=$ significant at 5\%, & 0 \\
*** $=$ significant at $1 \%$ (two sided). &
\end{tabular}

As with any study, the results need to be interpreted with caution. There are various supply and demand factors, such as price, access, and quality, among others, that affect health outcomes which are not included in the paper. ${ }^{6}$ Since the goal of this paper is to measure the expenditure efficiency, such factors were not included. Further examination including those factors might be needed to have a more holistic picture of differences among countries.

$6 \quad$ A detailed discussion of these supply and demand factors can be found in Filmer (2003). 


\section{Subnational Efficiency Analysis}

The same analysis we have done or a panel of ADB countries can also be done for a panel or cross-section of provinces within Countries. Box Tables 1, 2, and 3 show the DEA results for Indonesian and Indian provinces for health and education efficiencies.

Box Table 1: Indonesian Provinces Data Envelopment Analysis Results, 2010

\begin{tabular}{|c|c|c|c|c|}
\hline & \multicolumn{2}{|c|}{ Health } & \multicolumn{2}{|c|}{ Education } \\
\hline Indonesian provinces & Input Oriented & Output oriented & Input Oriented & Output Oriented \\
\hline Aceh & 0.03344007 & 0.889101483 & 0.034791763 & 0.200733883 \\
\hline Sumatera Barat & 0.15901753 & 0.867425317 & 0.166800923 & 0.157349455 \\
\hline Riau & 0.09769118 & 0.924910237 & 0.043120051 & 0.12928987 \\
\hline Kepulauan Riau & 0.49953383 & 0.973236957 & 0.165781683 & 0.240017262 \\
\hline Jambi & 0.16141236 & 0.91940158 & 0.17889946 & 0.273472934 \\
\hline Sumatera Selatan & 0.06510039 & 0.930778037 & 0.058176897 & 0.174832724 \\
\hline Aceh & 0.03344007 & 0.889101483 & 0.034791763 & 0.200733883 \\
\hline Sumatera Barat & 0.15901753 & 0.867425317 & 0.166800923 & 0.157349455 \\
\hline Riau & 0.09769118 & 0.924910237 & 0.043120051 & 0.12928987 \\
\hline Kepulauan Riau & 0.49953383 & 0.973236957 & 0.165781683 & 0.240017262 \\
\hline Jambi & 0.16141236 & 0.91940158 & 0.17889946 & 0.273472934 \\
\hline Sumatera Selatan & 0.06510039 & 0.930778037 & 0.058176897 & 0.174832724 \\
\hline $\begin{array}{l}\text { Kepulauan Bangka } \\
\text { Belitung }\end{array}$ & 0.41477336 & 0.909580429 & 0.413473509 & 0.3028275 \\
\hline Bengkulu & 0.25655969 & 0.953533366 & 0.437219362 & 0.308007802 \\
\hline Lampung & 0.19909458 & 0.958563229 & 0.126179351 & 0.335203995 \\
\hline DKI Jakarta & 0.0367239 & 0.974810887 & 0.004379861 & 0.059788473 \\
\hline Jawa Barat & 0.06813931 & 0.943951911 & 0.048281737 & 0.249082691 \\
\hline Banten & 0.13549587 & 0.885030157 & 0.163375149 & 0.388732964 \\
\hline Jawa Tengah & 0.05394424 & 0.968143246 & 0.110062226 & 0.513240054 \\
\hline DI Yokyakarta & 1.00000000 & 1.00000000 & 0.146880605 & 0.476136514 \\
\hline Jawa Timur & 0.02270965 & 0.942515064 & 0.100067878 & 0.578079792 \\
\hline Bali & 1.00000000 & 1.00000000 & 0.28143066 & 0.612993751 \\
\hline Nusa Tenggara Barat & 0.29096325 & 0.964550828 & 1.00000000 & 1.00000000 \\
\hline Nusa Tenggara Timur & 0.3368189 & 0.9486226 & 0.574522003 & 0.574835209 \\
\hline Kalimantan Barat & 0.12048617 & 0.891137724 & 0.372863819 & 0.549535999 \\
\hline Kalimantan Tengah & 0.2410671 & 0.899161712 & 0.143753031 & 0.184329793 \\
\hline Kalimantan Timur & 0.10011128 & 0.998443427 & 0.103989565 & 0.200086317 \\
\hline Sulawesi Utara & 1.00000000 & 1.00000000 & 0.330730065 & 0.032359231 \\
\hline Gorontalo & 1.00000000 & 1.00000000 & 0.662917874 & 0.228361753 \\
\hline Sulawesi Barat & 0.57781416 & 0.839154267 & 0.88049318 & 0.632203564 \\
\hline Sulawesi Tenggara & 0.23654806 & 0.920598389 & 0.572644838 & 0.527304068 \\
\hline Maluku & 0.25723296 & 0.824790565 & 0.218009039 & 0.142024615 \\
\hline Papua & 0.04950793 & 0.709221367 & 1.00000000 & 1.00000000 \\
\hline Papua Barat & 0.38675141 & 0.92862237 & 0.282493748 & 0.224627433 \\
\hline
\end{tabular}

Sources: Authors' calculations and Statistical Yearbook of Indonesia. 
Box continued

Box Table 2: India Education Data Envelopment Analysis Results, 2010

\begin{tabular}{|l|c|c|}
\hline Province & Input Oriented & Output Oriented \\
\hline Andhra Pradesh & 0.7731775 & 0.706336902 \\
\hline Assam & 0.912446 & 0.827944107 \\
\hline Bihar & 0.9960821 & 0.998820393 \\
\hline Chattisgarh & 1.00000000 & 1.00000000 \\
\hline Delhi & 0.6520263 & 0.91213412 \\
\hline Goa & 0.7193426 & 0.789749057 \\
\hline Gujarat & 1.00000000 & 1.00000000 \\
\hline Haryana & 0.843542 & 0.963389281 \\
\hline Himachal & 0.8846648 & 0.895441932 \\
\hline Jharkhand & 0.7315478 & 0.561722646 \\
\hline Karnataka & 0.7898173 & 0.649854075 \\
\hline Kerala & 0.6247294 & 0.828451682 \\
\hline Madhya Pradesh & 1.00000000 & 1.00000000 \\
\hline Maharashtra & 1.00000000 & 1.00000000 \\
\hline Manipur & 1.00000000 & 1.00000000 \\
\hline Meghalaya & 0.7741497 & 0.703299671 \\
\hline Mizoram & 0.6930572 & 0.794978913 \\
\hline Nagaland & 0.8595166 & 0.824135297 \\
\hline Odisha* & 0.7986397 & 0.790594456 \\
\hline Punjab & 0.7288752 & 0.752717309 \\
\hline Rajasthan & 1.00000000 & 1.00000000 \\
\hline Tamil Nadu & 0.846315 & 0.96597638 \\
\hline Tripura & 0.9483333 & 0.827916003 \\
\hline Uttar Pradesh & 1.00000000 & 1.00000000 \\
\hline Uttarkhand & 0.8246377 & 0.835965929 \\
\hline West Bengal & 0.8278718 & 0.903626434 \\
\hline Alsar & \\
\hline & & 0.000 \\
\hline
\end{tabular}

${ }^{*}$ Although these results are from 2010, in 2011 the Government of India approved the name change of the State of Orissa to Odisha. This document reflects this change.

Sources: Authors' calculations and National Databank of India. 
Box continued

Box Table 3: India Health Data Envelopment Analysis Results, 2008

\begin{tabular}{|l|l|l|}
\hline & $\begin{array}{c}\text { Input } \\
\text { Oriented, } \\
\text { Health }\end{array}$ & $\begin{array}{c}\text { Output } \\
\text { Oriented }\end{array}$ \\
\hline Andhra Pradesh & 0.06135316 & 0.933961454 \\
\hline Assam & 0.11623748 & 0.728302945 \\
\hline Bihar & 0.06520867 & 0.574257858 \\
\hline Chattisgarh & 0.20155039 & 0.848431886 \\
\hline Delhi & 0.08497286 & 0.873375413 \\
\hline Goa & 1.00000000 & 1.00000000 \\
\hline Gujarat & 0.0690156 & 0.763146146 \\
\hline Haryana & 0.13874066 & 0.730551976 \\
\hline Himachal & 0.60487947 & 0.998224159 \\
\hline Jharkhand & 0.12820513 & 0.74716358 \\
\hline Karnataka & 0.07869539 & 0.897776477 \\
\hline Kerala & 1.00000000 & 1.00000000 \\
\hline Madhya Pradesh & 0.06645537 & 0.604216099 \\
\hline Maharashtra & 0.03799359 & 0.889117293 \\
\hline Manipur & 0.80246914 & 0.86244517 \\
\hline Meghalaya & 0.63229572 & 0.557162971 \\
\hline Mizoram & 0.94843771 & 0.966556189 \\
\hline Odisha* & 0.10562236 & 0.858153271 \\
\hline Puducherry & 1.00000000 & 1.00000000 \\
\hline Punjab & 0.15532807 & 0.941051588 \\
\hline Rajasthan & 0.0551455 & 0.706816681 \\
\hline Sikkim & 1.00000000 & 1.00000000 \\
\hline Tamil Nadu & 1.00000000 & 1.00000000 \\
\hline Tripura & 0.61090226 & 0.765824617 \\
\hline Uttar Pradesh & 0.02484804 & 0.49457892 \\
\hline Uttarkhand & 0.23398128 & 0.873271686 \\
\hline West Bengal & 1.00000000 & 1.00000000 \\
\hline Atrough & fro \\
\hline
\end{tabular}

* Although these results are from 2008, in 2011 the Government of India approved the name change of the State of Orissa to Odisha. This document reflects this change.

Sources: Authors' calculations and National Databank of India. 


\section{DISTRIBUTION OF PUBLIC SPENDING}

\section{A. Inequalities in Utilization}

Inequalities still exists in Asia, even for the most basic health services such as immunization and skilled birth attendance. Table 15 shows utilization rates of full immunization broken down by quintiles. While utilization rates differ widely from 25.4 in Tajikistan to almost full coverage of the population in Thailand, what is common in these countries is that poorest quintiles have lower utilization compared to the richest quintiles.

Table 15: Equity in Full Immunization Utilization

\begin{tabular}{|l|c|c|c|c|c|c|c|}
\hline & Quintile 1 & 2 & 3 & 4 & 5 & Total & Cl \\
\hline Albania (2008-2009) & 91.3 & 91.5 & 89.7 & 86.9 & 91.7 & 90.2 & -0.002 \\
\hline Armenia (2005) & 63.1 & 57.1 & 79.3 & 64.6 & 50.8 & 62.0 & -0.003 \\
\hline Azerbaijan (2006) & 38.3 & 40.0 & 42.8 & 37.8 & 66.9 & 44.5 & $0.097^{* *}$ \\
\hline Bangladesh (2007) & 79.6 & 77.1 & 80.8 & 87.1 & 88.4 & 82.5 & $0.026^{* * *}$ \\
\hline Cambodia (2010) & 66.2 & 77.5 & 82.7 & 85.5 & 88.0 & 79.0 & $0.062^{* * *}$ \\
\hline India (2005-2006) & 24.6 & 33.5 & 47.5 & 56.0 & 71.6 & 43.9 & $0.215^{* * *}$ \\
\hline Indonesia (2007) & 39.9 & 53.8 & 58.3 & 68.2 & 75.0 & 58.9 & $0.121^{* * *}$ \\
\hline Kazakhstan (2006) & 82.1 & 58.0 & 59.7 & 86.2 & 70.1 & 71.0 & 0.035 \\
\hline Lao PDR (2006) & 58.8 & 68.0 & 83.2 & 85.3 & 92.4 & 76.7 & $0.090^{* * *}$ \\
\hline Mongolia (2005) & 91.0 & 95.7 & 96.9 & 96.5 & 96.7 & 95.2 & $0.013^{* * *}$ \\
\hline Nepal (2006) & 68.2 & 82.9 & 86.7 & 90.9 & 93.8 & 83.0 & $0.068^{* * *}$ \\
\hline Pakistan (2006-2007) & 26.8 & 41.6 & 53.6 & 60.2 & 65.0 & 48.7 & $0.171^{* * *}$ \\
\hline Philippines (2008) & 63.7 & 82.2 & 82.2 & 89.3 & 87.6 & 79.7 & $0.063^{* * *}$ \\
\hline Thailand (2005-2006) & 98.0 & 99.8 & 97.4 & 99.6 & 98.8 & 98.6 & 0.001 \\
\hline Timor-Leste (2009-2010) & 43.4 & 52.9 & 56.5 & 64.9 & 45.5 & 52.6 & $0.030^{* * *}$ \\
\hline Viet Nam (2006) & 44.0 & 74.3 & 90.4 & 72.1 & 95.9 & 77.8 & $0.120^{* * *}$ \\
\hline Tajikistan (2005) & 13.2 & 16.4 & 24.1 & 34.9 & 40.0 & 25.4 & $0.213^{* * *}$ \\
\hline
\end{tabular}

$\mathrm{Cl}=$ concentration index, Lao PDR = Lao People's Democratic Republic.

Sources: World Bank, Health Equity and Financial Protection Datasheets, various countries.

The same trend is true for the attendance of skilled professional during childbirth. In Bangladesh, only $18.2 \%$ of women benefit from skilled birth attendance, but among the richest quintiles, $50 \%$ are able to access skilled professionals, while only $5 \%$ of the poorest are able to do so. On the other end of the spectrum, Albania, Armenia, and the Philippines have near universal coverage in this indicator, but some pockets of the population, specifically those in the poorest two quintiles, are lagging behind (Table 16). 
Public Service Spending: Efficiency and Distributional Impact-Lessons from Asia | 35

Table 16: Equity in Skilled Birth Attendance Utilization

\begin{tabular}{|l|c|c|c|c|c|c|c|}
\hline & Quintile 1 & \multicolumn{1}{|c|}{$\mathbf{2}$} & $\mathbf{3}$ & $\mathbf{4}$ & $\mathbf{5}$ & Total & $\mathrm{Cl}$ \\
\hline Albania (2008-2009) & 98.7 & 99.2 & 99.4 & 100.0 & 100.0 & 99.4 & $0.003^{* * *}$ \\
\hline Armenia (2005) & 98.3 & 99.9 & 100.0 & 100.0 & 100.0 & 99.7 & $0.003^{* * *}$ \\
\hline Azerbaijan (2006) & 79.2 & 84.3 & 90.6 & 98.1 & 99.6 & 89.3 & $0.051^{* * *}$ \\
\hline Bangladesh (2007) & 4.9 & 6.5 & 12.9 & 23.1 & 50.7 & 18.2 & $0.479^{* * *}$ \\
\hline Cambodia (2010) & 49.5 & 64.2 & 75.4 & 87.2 & 97.3 & 71.9 & $0.143^{* * *}$ \\
\hline India (2005-2006) & 19.6 & 32.4 & 49.7 & 67.5 & 89.1 & 47.3 & $0.293^{* * *}$ \\
\hline Indonesia (2007) & 44.0 & 66.9 & 79.0 & 87.6 & 96.0 & 73.5 & $0.148^{* * *}$ \\
\hline Nepal (2006) & 8.0 & 13.3 & 15.5 & 30.2 & 61.6 & 22.7 & $0.411^{* * *}$ \\
\hline Pakistan (2006-2007) & 15.9 & 25.4 & 36.4 & 52.4 & 79.1 & 39.7 & $0.312^{* * *}$ \\
\hline Philippines (2008) & 97.1 & 98.7 & 99.5 & 99.6 & 99.7 & 98.7 & $0.005^{* * *}$ \\
\hline Timor-Leste (2009-2010) & 10.6 & 14.1 & 21.2 & 38.9 & 69.5 & 30.3 & $0.392^{* * *}$ \\
\hline Viet Nam (2002) & 58.2 & 86.2 & 95.1 & 97.4 & 99.7 & 85.2 & $0.101^{* * *}$ \\
\hline
\end{tabular}

$\mathrm{Cl}=$ concentration index.

Sources: World Bank, Health Equity and Financial Protection Datasheets, various countries.

The same unequal trends are observed in outpatient and inpatient utilization. It is worth noting though that Sri Lanka, Malaysia, and the Lao People's Democratic Republic have more poor quintiles utilizing inpatient services, compared to richer quintiles (Tables 17 and 18).

Table 17: Equity in Outpatient Utilization

\begin{tabular}{|l|c|c|c|c|c|c|c|}
\hline & Quintile 1 & $\mathbf{2}$ & $\mathbf{3}$ & $\mathbf{4}$ & $\mathbf{5}$ & Total & Cl \\
\hline Bangladesh (2003) & 77.8 & 80.7 & 82 & 80.5 & 81.1 & 80.3 & $0.009^{*}$ \\
\hline $\begin{array}{l}\text { China, People's Republic of } \\
\text { (2002) }\end{array}$ & 41.5 & 34.7 & 36.3 & 32.4 & 54.1 & 39.9 & $0.057^{* * *}$ \\
\hline Georgia (2003) & 22.3 & 31.4 & 31.2 & 32.4 & 32.9 & 30.5 & $0.047^{* *}$ \\
\hline India (2003) & 51.4 & 56.6 & 58.4 & 66.5 & 63.2 & 59.1 & $0.044^{* * *}$ \\
\hline Kazakhstan (2002-2003) & 57.3 & 61.2 & 65.5 & 54.2 & 53.1 & 58.2 & -0.023 \\
\hline Lao PDR (2003) & 9.2 & 10.9 & 15.3 & 18.3 & 21.8 & 14.9 & $0.183^{* * *}$ \\
\hline Malaysia (2003) & 43.1 & 40.3 & 36.7 & 39.7 & 42.7 & 40.5 & 0.000 \\
\hline Mongolia-all public (2007-2008) & 39.0 & 32.6 & 45.5 & 51.7 & 66.3 & 47.0 & $0.133^{* * *}$ \\
\hline Myanmar (2003) & 16.3 & 21.5 & 22.1 & 24.3 & 27.8 & 22.4 & $0.104^{* * *}$ \\
\hline Nepal (2003) & 27.4 & 28.4 & 34.2 & 38.6 & 42.3 & 34.0 & $0.101^{* * *}$ \\
\hline Pakistan (2003) & 52.9 & 60.6 & 63.1 & 74.3 & 67.1 & 63.6 & $0.054^{* * *}$ \\
\hline Philippines (2003) & 18.1 & 20.9 & 20.4 & 24.9 & 26.0 & 22.1 & $0.078^{* * *}$ \\
\hline Sri Lanka (2003) & 47.5 & 41.4 & 49.4 & 54.9 & 67.4 & 52.5 & $0.082^{* * *}$ \\
\hline Viet Nam (2002-2003) & 42.0 & 51.0 & 52.7 & 42.6 & 53.6 & 48.4 & $0.030^{* * *}$ \\
\hline
\end{tabular}

$\mathrm{Cl}=$ concentration index, Lao PDR = Lao People's Democratic Republic.

Sources: World Bank, Health Equity and Financial Protection Datasheets, various countries and years. 
Table 18: Equity in Inpatient Utilization (12 months)

\begin{tabular}{|l|c|c|c|c|c|c|c|}
\hline & Quintile 1 & 2 & 3 & 4 & 5 & Total & Cl \\
\hline Bangladesh (2003) & 2.8 & 4.0 & 6.4 & 3.8 & 7.2 & 4.8 & $0.155^{* * *}$ \\
\hline $\begin{array}{l}\text { China, People's Republic of } \\
\text { (2002) }\end{array}$ & 5.3 & 7.8 & 8.6 & 6.0 & 6.3 & 6.8 & 0.011 \\
\hline Georgia (2003) & 4.1 & 5.0 & 4.3 & 3.0 & 4.3 & 4.2 & -0.044 \\
\hline India (2003) & 6.5 & 5.8 & 6.6 & 8.6 & 9.1 & 7.3 & $0.093^{* * *}$ \\
\hline Kazakhstan (2002-2003) & 10.2 & 8.6 & 9.6 & 5.6 & 9.4 & 8.7 & -0.025 \\
\hline Lao PDR (2003) & 2.6 & 3.7 & 4.6 & 3.4 & 5.0 & 3.9 & $0.101^{* * *}$ \\
\hline Malaysia (2003) & 8.8 & 10.2 & 9.3 & 6.6 & 8.7 & 8.7 & -0.032 \\
\hline Mongolia-all public (2007-2008) & 8.6 & 7.4 & 7.5 & 8.1 & 8.9 & 8.1 & $0.013^{* * *}$ \\
\hline Myanmar (2003) & 1.2 & 2.1 & 1.6 & 2.5 & 2.5 & 2.0 & $0.124^{* * *}$ \\
\hline Nepal (2003) & 5.0 & 5.2 & 4.9 & 5.3 & 7.5 & 5.6 & 0.079 \\
\hline Pakistan (2003) & 6.0 & 7.4 & 6.3 & 4.1 & 6.8 & 6.1 & -0.012 \\
\hline Philippines (2003) & 5.5 & 6.4 & 5.5 & 6.7 & 9.5 & 6.7 & $0.106^{* * *}$ \\
\hline Sri Lanka (2003) & 12.9 & 9.5 & 12.9 & 8.8 & 8.5 & 10.5 & -0.061 \\
\hline Viet Nam (2002-2003) & 9.3 & 6.3 & 7.2 & 7.5 & 9.5 & 8.1 & 0.000 \\
\hline
\end{tabular}

$\mathrm{Cl}=$ concentration index, Lao PDR = Lao People's Democratic Republic.

Sources: World Bank, Health Equity and Financial Protection datasheets, various countries.

\section{B. Inequalities in Government Subsidies}

Given the trends in utilization, it is not surprising that most government subsidies go to the richest quintiles (Table 19). In the 1990s, the largest subsidies go to hospital care for the richest quintile. This seems to prevail in Bangladesh in 2005, but this does not seem to be the case anymore for Mongolia and Viet Nam in 2006. In Mongolia, there appears to be a differentiation in suom and aimag facilitieswith aimag facilities being more pro-poor. In Viet Nam, the poor benefit most from subsidies in commune health centers, while richer quintiles benefit on services that are hospital based.

Table 19: Benefit Incidence of Public Expenditure on Health, Selected Economies and Years

\begin{tabular}{|c|c|c|c|c|c|c|}
\hline & Quintile 1 & 2 & 3 & 4 & 5 & $\mathrm{Cl}$ \\
\hline \multicolumn{7}{|l|}{ Bangladesh (2005) } \\
\hline Outpatient-primary & 16 & 18 & 21 & 27 & 18 & \\
\hline Outpatient-secondary & 18 & 24 & 21 & 20 & 17 & \\
\hline Outpatient-tertiary & 11 & 22 & 15 & 20 & 32 & \\
\hline Outpatient-other GOB & 8 & 15 & 10 & 33 & 34 & \\
\hline Inpatient-primary & 11 & 9 & 15 & 25 & 40 & \\
\hline Inpatient-secondary & 21 & 10 & 14 & 15 & 40 & \\
\hline Inpatient-tertiary & 8 & 12 & 8 & 23 & 49 & \\
\hline Inpatient-other GOB & 7 & 7 & 0 & 20 & 66 & \\
\hline Outpatient-total & 14 & 20 & 18 & 25 & 23 & \\
\hline Inpatient-total & 12 & 10 & 13 & 24 & 31 & \\
\hline
\end{tabular}


Table 19 continued

\begin{tabular}{|c|c|c|c|c|c|c|}
\hline & Quintile 1 & 2 & 3 & 4 & 5 & $\mathrm{Cl}$ \\
\hline \multicolumn{7}{|l|}{ Mongolia (2006) } \\
\hline Outpatient suom hospital/family group practice & 25.3 & 18.0 & 22.0 & 18.4 & 16.3 & -0.072 \\
\hline Outpatient aimag and central hospital & 18.5 & 15.0 & 19.3 & 23.0 & 24.2 & 0.075 \\
\hline Inpatient suom hospital/family group practice & 30.6 & 20.1 & 20.2 & 17.1 & 12.0 & -0.071 \\
\hline Inpatient aimag and central hospital & 18.8 & 18.0 & 18.4 & 20.8 & 24.0 & 0.053 \\
\hline Total & 21.5 & 17.6 & 19.4 & 20.5 & 21.1 & 0.008 \\
\hline \multicolumn{7}{|l|}{ Viet Nam (2006) } \\
\hline Outpatient commune health center & 27.8 & 21.5 & 19.4 & 17.8 & 13.4 & -0.141 \\
\hline Outpatient polyclinic & 19.8 & 20.4 & 13.9 & 23.5 & 22.4 & 0.034 \\
\hline Outpatient general hospital & 9.9 & 14.1 & 16.8 & 26.2 & 33.0 & 0.247 \\
\hline Inpatient general hospital & 17.4 & 20.0 & 22.1 & 20.9 & 19.7 & 0.022 \\
\hline Total & 13.6 & 16.9 & 19.2 & 23.6 & 26.7 & 0.138 \\
\hline \multicolumn{7}{|l|}{ Asia and Pacific (1990s) } \\
\hline Primary health care & 19.7 & & & & 16.9 & \\
\hline Health centers & 18.4 & & & & 16.8 & \\
\hline Hospitals & 9.1 & & & & 38.0 & \\
\hline Total & 10.8 & & & & 30.9 & \\
\hline
\end{tabular}

$\mathrm{Cl}=$ concentration index, $\mathrm{GOB}=$ Government of Bangladesh .

Sources: World Bank, Mongolia and Viet Nam Health Equity and Financial Protection Datasheets; Bangladesh Public Expenditure Review 2010; and Davoodi, Tiongson, and Asawanuchit 2010.

Benefit analysis in various economies show that in education, the poorest quintiles benefit more on subsidies in primary education spending, while richer quintiles benefit more on secondary and tertiary expenditures. With the exception of Armenia, this trend is consistent in all economies in Table 20. This trend was also observed in the region for the 1990s.

\section{Table 20: Benefit Incidence of Public Expenditure on Primary and Secondary Education, Selected Economies and Years}

\begin{tabular}{|l|c|c|c|c|c|}
\hline & \multicolumn{5}{|c|}{ Income Quintiles } \\
\hline & 1 & 2 & 3 & 4 & 5 (Richest) \\
\hline $\begin{array}{l}\text { Bangladesh (2005, recurrent spending, } \\
\text { primary) }\end{array}$ & 24 & 23 & 21 & 18 \\
\hline $\begin{array}{l}\text { Bangladesh (2005, recurrent spending, } \\
\text { secondary }\end{array}$ & 12 & 14 & 20 & 27 & 27 \\
\hline $\begin{array}{l}\text { Bangladesh (2005, recurrent spending, } \\
\text { upper Secondary) }\end{array}$ & 3 & 8 & 11 & 22 & 56 \\
\hline Viet Nam (2002, primary) & 31 & 23 & 18 & 15 & 13 \\
\hline Viet Nam (2002, secondary & 20 & 23 & 23 & 20 & 14 \\
\hline Viet Nam (2002, upper secondary) & 9 & 16 & 22 & 28 & 26 \\
\hline Viet Nam (1998, primary) & 26 & 25 & 21 & 16 & 12 \\
\hline Viet Nam (1998, secondary) & 13 & 19 & 23 & 24 & 21 \\
\hline Viet Nam (1998, upper secondary) & 4 & 11 & 17 & 21 & 30 \\
\hline Armenia (2003, primary) & 15 & 23 & 23 \\
\hline
\end{tabular}


Table 20 continued

\begin{tabular}{|c|c|c|c|c|c|}
\hline & \multicolumn{5}{|c|}{ Income Quintiles } \\
\hline & 1 & 2 & 3 & 4 & 5 (Richest) \\
\hline Armenia (2003, secondary) & 15 & 17 & 20 & 22 & 26 \\
\hline Cambodia (2002, primary) & 25 & 25 & 21 & 17 & 12 \\
\hline Cambodia (2002, secondary) & 11 & 14 & 19 & 22 & 34 \\
\hline Cambodia (2002, upper secondary) & 7 & 7 & 13 & 26 & 46 \\
\hline Lao PDR (2002-2003 data, primary) & 21 & 23 & 22 & 20 & 15 \\
\hline Lao PDR (2002-2003 data, secondary) & 9 & 16 & 20 & 27 & 28 \\
\hline $\begin{array}{l}\text { Lao PDR (2002-2003 data, upper } \\
\text { secondary) }\end{array}$ & 8 & 12 & 19 & 26 & 40 \\
\hline Asia and the Pacific (1990s, primary) & 20 & -- & -- & -- & 16 \\
\hline Asia and the Pacific (1990s, secondary) & 8 & -- & -- & -- & 37 \\
\hline Asia and the Pacific (1990s, tertiary) & 2 & -- & -- & -- & 69 \\
\hline
\end{tabular}

Lao PDR = Lao People's Democratic Republic.

Sources: World Bank, Public Expenditure Reviews, various countries and years; Davoodi, Tiongson, and Asawanuchit 2010.

\section{CONCLUSIONS AND POLICY RECOMMENDATIONS}

The paper analyzed the efficiency of health and education expenditure in Asian countries using DEA. The results indicate that countries could achieve higher health and education outcomes given their expenditures. The health output efficiency score of 0.96 implies that the three health outcome indicators can be increased further by $4 \%$. On average, in terms of input efficiency, Asian countries can use $93 \%$ of their budget to attain current levels of health indicators. Since these figures are just indicative, it is important to identify the factors that cause the variations in efficiency scores. The Tobit regression identified variables that show statistical association with efficiency scores. Results show countries where other factors affecting access, such as roads, are efficient.

To improve allocative efficiency of public spending, at the same time make expenditures propoor, there is a need to reallocate expenditures from hospitals to public health, and tertiary and secondary to primary education. It has become evident in this study that many countries still favor curative health spending and tertiary education spending despite evidence that the benefits of these expenditures do not accrue to the poor.

Adoption of performance based budgeting will help align incentives to performance as well as improve efficiency of input mix. It was found that most countries normally practice historical budgeting, which does not necessarily reflect the current needs of institutions and does not encourage improvements in performance.

In health, TE will improve if referral systems are put in place. Most countries, even relatively good performers like Sri Lanka, appear to be struggling in ensuring that patients do not bypass primary care. Countries like the United Kingdom have successfully done this assigned gate-keeping functions 
to primary care providers, but for low- and middle-income countries, this would also entail improvements in the perception of primary care providers.

Improvements in budget execution need citizen participation. Experiences of Bangladesh and the Philippines show that accountability of ministries and politicians improve when civil organizations are involved in expenditure tracking. Leakages will also be minimized when the public are given access to information, such as Public Expenditure Tracking Surveys. Also, as nongovernment organizations and other sectors get involved in service provision, governments should ensure that regulatory frameworks are being drawn up to standardize delivery of quality services.

Lastly, better provision of public services entails sustained tax reform process. Encouraging participation of civil society groups in tax-watch efforts will help ensure that the taxes are indeed being spent in necessary public services that the poor need most. 


\section{APPENDIX}

\section{Appendix Table 1: Health Expenditure Efficiency Scores, 1995-2010}

\begin{tabular}{|c|c|c|c|c|c|c|c|c|c|c|c|c|c|c|c|c|c|c|}
\hline Country & Region & 1995 & 1996 & 1997 & 1998 & 1999 & 2000 & 2001 & 2002 & 2003 & 2004 & 2005 & 2006 & 2007 & 2008 & 2009 & 2010 & $\begin{array}{l}\text { Country } \\
\text { Average }\end{array}$ \\
\hline Afghanistan & South Asia & 1.000 & 0.571 & 1.000 & 1.000 & 1.000 & 1.000 & 1.000 & 1.000 & 1.000 & 0.832 & 0.934 & 0.913 & 0.885 & 0.881 & 0.867 & 0.839 & 0.920 \\
\hline Armenia & Central Asia & 0.952 & 0.822 & 0.783 & 0.758 & 0.909 & 0.887 & 0.927 & 0.967 & 0.900 & 0.899 & 0.889 & 0.829 & 0.847 & 0.848 & 0.857 & 0.913 & 0.874 \\
\hline Azerbaijan & Central Asia & 0.866 & 0.827 & 0.769 & 0.932 & 0.952 & 0.948 & 0.937 & 0.926 & 0.904 & 0.907 & 0.870 & 0.893 & 0.905 & 0.889 & 0.845 & 0.857 & 0.889 \\
\hline Bangladesh & South Asia & 0.632 & 0.844 & 0.722 & 0.908 & 0.912 & 0.975 & 0.951 & 1.000 & 1.000 & 1.000 & 0.957 & 0.873 & 0.923 & 0.907 & 0.827 & 0.942 & 0.898 \\
\hline Bhutan & South Asia & 0.868 & 0.877 & 0.833 & 0.944 & 1.000 & 1.000 & 0.980 & 0.899 & 0.969 & 0.854 & 0.954 & 0.936 & 0.924 & 0.889 & 0.801 & 0.875 & 0.913 \\
\hline Brunei Darussalam & Southeast Asia & 1.000 & 1.000 & 1.000 & 1.000 & 1.000 & 1.000 & 1.000 & 1.000 & 1.000 & 1.000 & 1.000 & 0.987 & 1.000 & 1.000 & 1.000 & 1.000 & 0.999 \\
\hline Cambodia & Southeast Asia & 0.676 & 0.429 & 0.906 & 0.861 & 0.762 & 0.731 & 0.899 & 0.920 & 0.859 & 0.880 & 0.905 & 0.744 & 0.887 & 0.898 & 0.822 & 0.909 & 0.818 \\
\hline $\begin{array}{l}\text { China, People's } \\
\text { Republic of }\end{array}$ & East Asia & 0.783 & 0.826 & 0.816 & 0.883 & 0.917 & 0.906 & 0.872 & 0.900 & 0.883 & 0.903 & 0.921 & 0.899 & 0.901 & 0.949 & 0.972 & 0.984 & 0.895 \\
\hline Fiji & The Pacific & 0.955 & 0.972 & 0.907 & 0.879 & 1.000 & 0.951 & 0.974 & 0.978 & 0.973 & 0.940 & 1.000 & 1.000 & 1.000 & 1.000 & 1.000 & 1.000 & 0.971 \\
\hline Georgia & Central Asia & 1.000 & 1.000 & 0.985 & 1.000 & 1.000 & 1.000 & 1.000 & 0.968 & 0.861 & 0.798 & 0.822 & 0.798 & 0.964 & 0.878 & 0.906 & 0.897 & 0.929 \\
\hline India & South Asia & 0.723 & 0.611 & 0.869 & 1.000 & 1.000 & 0.915 & 0.965 & 0.926 & 0.848 & 0.837 & 0.818 & 0.732 & 0.738 & 0.746 & 0.736 & 0.776 & 0.828 \\
\hline Indonesia & Southeast Asia & 0.814 & 0.639 & 0.657 & 0.799 & 0.821 & 0.804 & 0.821 & 0.801 & 0.775 & 0.749 & 0.757 & 0.684 & 0.829 & 0.725 & 0.767 & 0.813 & 0.766 \\
\hline Kazakhstan & Central Asia & 0.878 & 0.905 & 0.948 & 1.000 & 0.941 & 0.889 & 0.912 & 0.891 & 0.943 & 0.689 & 0.959 & 1.000 & 0.859 & 1.000 & 0.899 & 1.000 & 0.919 \\
\hline Kiribati & The Pacific & 0.954 & 0.963 & 0.951 & 0.888 & 1.000 & 0.953 & 0.969 & 0.721 & 0.822 & 0.938 & 0.800 & 1.000 & 0.932 & 0.919 & 0.805 & 0.936 & 0.909 \\
\hline Korea, Republic of & East Asia & 1.000 & 0.936 & 0.994 & 1.000 & 0.996 & 0.968 & 1.000 & 1.000 & 1.000 & 0.964 & 1.000 & 1.000 & 1.000 & 1.000 & 1.000 & 1.000 & 0.991 \\
\hline Kyrgyz Republic & Central Asia & 0.860 & 0.951 & 0.969 & 0.827 & 0.960 & 1.000 & 1.000 & 0.943 & 0.919 & 0.992 & 0.959 & 0.808 & 0.870 & 0.881 & 0.813 & 0.908 & 0.916 \\
\hline Lao PDR & Southeast Asia & 0.631 & 0.383 & 0.704 & 0.721 & 0.747 & 1.000 & 1.000 & 0.948 & 1.000 & 1.000 & 1.000 & 1.000 & 1.000 & 1.000 & 0.881 & 0.940 & 0.872 \\
\hline Malaysia & Southeast Asia & 0.988 & 1.000 & 1.000 & 0.903 & 1.000 & 0.964 & 0.963 & 0.997 & 0.943 & 0.937 & 1.000 & 0.884 & 0.856 & 0.965 & 0.895 & 0.923 & 0.951 \\
\hline Maldives & South Asia & 0.885 & 0.962 & 0.958 & 0.827 & 0.949 & 0.941 & 0.972 & 1.000 & 0.963 & 0.934 & 1.000 & 0.992 & 0.973 & 0.984 & 0.961 & 0.949 & 0.953 \\
\hline Marshall Islands & The Pacific & 1.000 & 1.000 & 1.000 & 0.724 & 0.818 & 0.751 & 1.000 & 1.000 & 0.839 & 1.000 & 0.855 & 0.801 & 0.928 & 1.000 & 1.000 & 0.923 & 0.915 \\
\hline $\begin{array}{l}\text { Micronesia, } \\
\text { Federated States of }\end{array}$ & The Pacific & 0.782 & 0.767 & 0.698 & 0.799 & 0.869 & 0.852 & 0.795 & 0.826 & 0.891 & 0.804 & 0.927 & 0.809 & 0.737 & 0.843 & 0.868 & 0.957 & 0.826 \\
\hline Mongolia & East Asia & 0.887 & 0.893 & 0.879 & 0.781 & 0.914 & 0.875 & 0.912 & 0.900 & 0.930 & 0.992 & 1.000 & 1.000 & 0.895 & 0.912 & 0.843 & 0.927 & 0.909 \\
\hline Nepal & South Asia & 0.752 & 0.595 & 0.712 & 0.843 & 0.673 & 0.869 & 0.857 & 0.821 & 0.832 & 0.899 & 0.841 & 0.930 & 0.918 & 0.983 & 0.794 & 0.825 & 0.822 \\
\hline Pakistan & South Asia & 1.000 & 0.773 & 0.942 & 1.000 & 1.000 & 0.857 & 0.918 & 0.890 & 0.892 & 0.774 & 0.883 & 0.772 & 0.892 & 0.659 & 0.810 & 0.920 & 0.874 \\
\hline Palau & The Pacific & 1.000 & 1.000 & 1.000 & 1.000 & 1.000 & 1.000 & 1.000 & 1.000 & 1.000 & 1.000 & 1.000 & 1.000 & 1.000 & 0.920 & 1.000 & 1.000 & 0.995 \\
\hline Papua New Guinea & The Pacific & 1.000 & 1.000 & 0.924 & 0.816 & 0.836 & 0.767 & 0.896 & 0.843 & 0.875 & 0.824 & 0.771 & 0.764 & 0.805 & 0.963 & 0.945 & 0.945 & 0.873 \\
\hline Philippines & Southeast Asia & 0.750 & 0.733 & 0.734 & 0.846 & 0.864 & 0.835 & 0.833 & 0.777 & 0.777 & 0.797 & 0.878 & 0.771 & 0.832 & 0.878 & 0.785 & 0.883 & 0.811 \\
\hline Singapore & Southeast Asia & 1.000 & 1.000 & 1.000 & 1.000 & 1.000 & 1.000 & 1.000 & 1.000 & 1.000 & 1.000 & 1.000 & 1.000 & 1.000 & 1.000 & 1.000 & 1.000 & 1.000 \\
\hline Solomon Islands & The Pacific & 0.740 & 0.557 & 0.740 & 0.861 & 0.760 & 0.812 & 0.904 & 0.876 & 0.874 & 0.912 & 0.946 & 0.893 & 0.850 & 1.000 & 1.000 & 0.984 & 0.856 \\
\hline Sri Lanka & South Asia & 0.959 & 0.930 & 0.979 & 0.772 & 1.000 & 0.993 & 0.971 & 0.984 & 1.000 & 0.975 & 1.000 & 0.967 & 0.960 & 0.963 & 0.921 & 1.000 & 0.961 \\
\hline Tajikistan & Central Asia & 0.894 & 0.696 & 0.690 & 0.748 & 0.871 & 0.796 & 0.831 & 0.765 & 0.742 & 0.776 & 0.872 & 0.777 & 0.885 & 0.843 & 0.851 & 0.914 & 0.809 \\
\hline Thailand & Southeast Asia & 0.969 & 0.947 & 0.934 & 0.840 & 0.973 & 0.940 & 0.963 & 0.979 & 0.954 & 1.000 & 1.000 & 0.991 & 0.977 & 1.000 & 0.987 & 1.000 & 0.966 \\
\hline Timor-Leste & The Pacific & 0.750 & 0.429 & 0.809 & 0.829 & 0.855 & 0.772 & 0.886 & 0.848 & 0.840 & 0.830 & 0.959 & 0.841 & 0.866 & 0.843 & 0.778 & 0.870 & 0.813 \\
\hline Tonga & The Pacific & 0.921 & 1.000 & 0.918 & 0.868 & 0.907 & 0.870 & 0.923 & 0.898 & 0.928 & 1.000 & 1.000 & 1.000 & 0.960 & 1.000 & 0.966 & 0.982 & 0.946 \\
\hline Turkmenistan & Central Asia & 0.907 & 0.933 & 0.960 & 0.967 & 0.959 & 0.917 & 0.884 & 1.000 & 0.696 & 0.899 & 0.988 & 0.929 & 0.934 & 0.889 & 0.788 & 0.908 & 0.909 \\
\hline Uzbekistan & Central Asia & 0.811 & 0.924 & 0.927 & 1.000 & 1.000 & 0.990 & 1.000 & 1.000 & 0.919 & 1.000 & 0.983 & 0.886 & 0.911 & 0.939 & 0.933 & 0.959 & 0.949 \\
\hline Vanuatu & The Pacific & 0.912 & 0.827 & 0.789 & 0.997 & 1.000 & 1.000 & 1.000 & 1.000 & 1.000 & 1.000 & 1.000 & 1.000 & 1.000 & 1.000 & 1.000 & 1.000 & 0.970 \\
\hline Viet Nam & Southeast Asia & 0.878 & 0.896 & 0.896 & 0.784 & 0.923 & 0.879 & 0.921 & 0.766 & 1.000 & 0.929 & 0.952 & 0.933 & 1.000 & 0.938 & 0.899 & 0.893 & 0.905 \\
\hline Mean & & 0.878 & 0.827 & 0.876 & 0.884 & 0.923 & 0.911 & 0.938 & 0.920 & 0.909 & 0.907 & 0.932 & 0.896 & 0.912 & 0.919 & 0.890 & 0.930 & 0.903 \\
\hline
\end{tabular}

Lao PDR = Lao People's Democratic Republic

Source: Authors' calculations. 
Appendix Table 2: Health Expenditure Efficiency, Country Peers

\begin{tabular}{|c|c|c|c|}
\hline & \multicolumn{3}{|c|}{ Peers } \\
\hline Afghanistan & Vanuatu & & \\
\hline Armenia & Singapore & Vanuatu & Fiji \\
\hline Azerbaijan & Vanuatu & Fiji & \\
\hline Bangladesh & Vanuatu & Fiji & \\
\hline Bhutan & Fiji & Vanuatu & \\
\hline \multicolumn{4}{|l|}{ Brunei Darussalam } \\
\hline Cambodia & Vanuatu & Fiji & \\
\hline China, People's Republic of & Thailand & Thailand & \\
\hline \multicolumn{4}{|l|}{ Fiji } \\
\hline Georgia & Singapore & Vanuatu & Fiji \\
\hline India & Fiji & Vanuatu & \\
\hline Indonesia & Vanuatu & Fiji & \\
\hline \multicolumn{4}{|l|}{ Kazakhstan } \\
\hline Kiribati & Singapore & Fiji & Vanuatu \\
\hline \multicolumn{4}{|l|}{ Korea, Republic of } \\
\hline Kyrgyz Republic & Fiji & Vanuatu & \\
\hline Lao PDR & Vanuatu & Fiji & \\
\hline Malaysia & Fiji & Singapore & Vanuatu \\
\hline Maldives & Fiji & Singapore & Vanuatu \\
\hline Marshall Islands & Singapore & Fiji & Vanuatu \\
\hline Micronesia, Federated States of & Singapore & Fiji & Vanuatu \\
\hline Mongolia & Vanuatu & Fiji & \\
\hline Nepal & Vanuatu & Fiji & \\
\hline Pakistan & Vanuatu & Fiji & \\
\hline \multicolumn{4}{|l|}{ Palau } \\
\hline Papua New Guinea & Vanuatu & & \\
\hline Philippines & Fiji & Vanuatu & \\
\hline \multicolumn{4}{|l|}{ Singapore } \\
\hline Solomon Islands & Vanuatu & Fiji & \\
\hline \multicolumn{4}{|l|}{ Sri Lanka } \\
\hline Tajikistan & Vanuatu & Fiji & \\
\hline \multicolumn{4}{|l|}{ Thailand } \\
\hline Timor-Leste & Vanuatu & Fiji & \\
\hline Tonga & Thailand & Kazakhstan & Fiji \\
\hline Turkmenistan & Fiji & Vanuatu & \\
\hline Uzbekistan & Fiji & & \\
\hline \multicolumn{4}{|l|}{ Vanuatu } \\
\hline Viet Nam & Fiji & Singapore & Vanuatu \\
\hline
\end{tabular}

Lao PDR = Lao People's Democratic Republic.

Source: Authors' calculations. 
Appendix Table 3: Codes of Economies

\begin{tabular}{|c|c|}
\hline Economy & Code \\
\hline Afghanistan & AFG \\
\hline Armenia & ARM \\
\hline Australia & AUS \\
\hline Azerbaijan & AZE \\
\hline Bangladesh & BAN \\
\hline Bhutan & $\mathrm{BHU}$ \\
\hline Brunei Darussalam & BRU \\
\hline Cambodia & CAM \\
\hline China, People's Republic of & PRC \\
\hline Fiji & FIJ \\
\hline Georgia & GEO \\
\hline Hong Kong, China & HKG \\
\hline India & IND \\
\hline Indonesia & INO \\
\hline Japan & JPN \\
\hline Kazakhstan & KAZ \\
\hline Kiribati & KIR \\
\hline Korea, Republic of & KOR \\
\hline Kyrgyz Republic & KGZ \\
\hline Lao PDR & LAO \\
\hline Malaysia & $\mathrm{MAL}$ \\
\hline Maldives & MLD \\
\hline Marshall Islands & RMI \\
\hline Micronesia, Federated States of & FSM \\
\hline Mongolia & MON \\
\hline Myanmar & MYA \\
\hline Nepal & NEP \\
\hline New Zealand & NZL \\
\hline Pakistan & PAK \\
\hline Palau & PAL \\
\hline Papua New Guinea & PNG \\
\hline Philippines & $\mathrm{PHI}$ \\
\hline Samoa & SAM \\
\hline Singapore & SIN \\
\hline Solomon Islands & SOL \\
\hline Sri Lanka & SRI \\
\hline Tajikistan & TAJ \\
\hline Thailand & THA \\
\hline Timor-Leste & TIM \\
\hline Tonga & TON \\
\hline Turkmenistan & TKM \\
\hline Tuvalu & TUV \\
\hline Uzbekistan & UZB \\
\hline Vanuatu & VAN \\
\hline Viet Nam & VIE \\
\hline
\end{tabular}

Source: ADB. 


\section{REFERENCES}

Afonso, A. and M. St. Aubyn. 2004. Non-Parametric Approaches to Education and Health Expenditure Efficiency in OECD Countries. Portugal: Instituto Superior de Economia e Gestao. pp. 1-34.

Afonso, A., L. Schuknecht, and V. Tanzi. 2005. Public Sector Efficiency: An International Comparison. Public Choice. 123 (3-4). pp. 321-47.

Banker, R. D., H. Chang, and W.W. Cooper. 2004. A Simulation Study of DEA and Parametric Frontier Models in the Presence of Heteroscedasticity. European Journal of Operational Research. 153 (3). pp. 624-40.

Banker, R. D., A. Charnes, and W. W. Cooper. 1984. Some Models for Estimating Technical and Scale Efficiencies in Data Envelopment Analysis. Management Science. 30 (9). pp. 1078-92.

Bergh, A. and G. Fink. 2004. Higher Education: Does Public Expenditure Increase Enrollment?

Bhat, R., B. Verma, and E. Reuben. 2001. Hospital Efficiency and Data Envelopment Analysis. Ahmedabad: Indian Institute of Management.

Bowlin, W. F. 2000. Measuring Performance: An Introduction to Data Envelopment Analysis (DEA). lowa: Department of Accounting, University of Northern lowa.

Charnes, A., W.W. Cooper, and E. Rhodes, 1978. Measuring Efficiency of Decision Making Units. European Journal of Operational Research. 2 (6). pp. 429-44.

- - 1981. Evaluating Program and Managerial Efficiency: An Application of Data Envelopment Analysis to Program Follow Through. Management Science. 27 (6). pp. 668-97.

Coelli, T. 1996. A Guide to DEAP Version 2.1: A Data Envelopment Analysis (Computer) Program. University of New England.

Coelli, T., P. Rao, and G. Battese. 1998. An Introduction to Efficiency and Productivity Analysis. USA: Kluwer Academic Publishers.

Davoodi, H., R. Tiongson, and S. Asawanuchit. 2010. Benefit Incidence of Public Education and Health Spending Worldwide: Evidence from a New Database. Poverty and Public Policy. Vol. No. 2, Issue No. 2, Article No. 2.

Evans, D., A. Tandon, C. Murray, and J. Lauer. 2000. The Comparative Efficiency of National Health Systems in Producing Health: An Analysis of 191 Countries. Geneva: World Health Organization.

Farrell, M. 1957. The Measurement of Productive Efficiency. Journal of the Royal Statistical Society. 120 (3). pp. 253-90.

Filmer, D. 2003. Determinants of Health and Education Outcomes. Background note for World Development Report 2004. The World Bank. Mimeo. 24 May. 
Fried, H., C. Lovell, and S. Schmidt. 1993. The Measurement of Productive Efficiency: Techniques and Applications. New York: Oxford University Press.

Government of Tonga and Australian Aid. 2010. Review of Public Expenditure on Health. http://www.ausaid.gov.au/countries/pacific/tonga/Documents/tonga\%20health\%20public\%2 Oexpenditure\%20review\%20report\%202010.pdf (accessed 30 January 2013).

Greene, W. 2003a. Distinguishing between Heterogeneity and Inefficiency: Stochastic Frontier Analysis of the World Health Organization's Panel Data on National Health Care Systems. New York University.

- - . 2003b. Fixed Effects and Bias Due to the Incidental Parameters Problem in the Tobit Model. New York University.

Gong, B. and R. Sickles. 1992. Finite Sample Evidence on the Performance of Stochastic Frontiers and Data Envelopment Analysis Using Panel Data. Journal of Econometrics. 51 (1-2). pp. 259-84.

Grosskopf, S. 1996. Statistical Inference and Non-Parametric Efficiency: A Selective Survey. Journal of Productivity Analysis. 7 (2-3). pp. 161-76.

Gupta, S. and M. Verhoeven. 2001. The Efficiency of Government Expenditure Experiences in Africa. Journal of Policy Modeling. 23 (4). pp. 433-67.

Herrera, H. and G. Pang. 2005. Efficiency of Public Spending in Developing Countries: An Efficiency Frontier Approach. Policy Research Working Paper No. 3645. Washington, DC: World Bank.

Hollingsworth, B. 2003. Non-Parametric and Parametric Applications Measuring Efficiency in Health Care. Health Care Management Science. 6 (4). pp. 203-18.

Hollingsworth, B. and J. Wildman. 2003. The Efficiency of Health Production: Re-Estimating the Who Panel Data Using Parametric and Non-Parametric Approaches to Provide Additional Information. Health Economics. 12 (6). pp. 493-504.

Independent Pricing and Regulatory Tribunal (IPART). 1999. Efficiency and Benchmarking Study of the NSW Distribution Businesses. Sydney: Commissioned by the Independent Pricing and Regulatory Tribunal of New South Wales. Prepared by London Economics.

James, C. D., D. Bayarsaikhan, and H. Bekedam. 2010. Health-Financing Strategy for WHO's AsiaPacific Region. The Lancet. 375 (9724). pp. 1417-19.

Maddala, G. S. 1987. Limited Dependent Variable Models Using Panel Data. The Journal of Human Resources. 22 (3). pp. 307-38.

Ministry of Health. 2012. Join Health Sector Review: Bhutan, Final Report. Bhutan. http://www.health.gov.bt/sowa/reports/JHSR_TechnicalReport2012.pdf (accessed 30 January 2013). 
Nepal Health Economics Association. 2009. Public Expenditure Review on Health Sector 2003/04 to 2005/06. Kathmandu. http://www.mohp.gov.np/english/publication/Public\%20Expenditure \%20Review\%20 of\%20Health.pdf (accessed 30 January 2013).

O’Donnell, O., E. Van Doorslaer, R. Rannan-Eliya, A. Somanathan, S. Adhikari, D. Harbianto, C. Garg, P. Hanvoravongchai, M. Huq, A. Karan, G. Leung, C. Ng, B. Pande, K. Tin, K. Tisayaticom, L. Trisnantoro, Y. Zhang, and Y. Zhao. 2007. The Incidence of Public Spending on Healthcare: Comparative Evidence from Asia. The World Bank Economic Review. 21 (1). pp. 93-123.

Ortiz, I., J. Chai, M. Cummins, and G. Vergara. 2010. Prioritizing Expenditures for a Recovery for All. A Rapid Review of Public Expenditures in 126 Developing Countries. Social and Economic Policy Working Paper. http://www.unicef.org/socialpolicy/files/Prioritizing_Expenditures_for_a _Recovery_for_All_October_11_final.pdf

Psacharopoulos, G. and H. Patrinos. 2004. Returns to Investment in Education: A Further Update. Education Economics. 12 (2). pp. 111-34

Ravallion, M. 2003. On Measuring Aggregate Social Efficiency. World Bank Policy Research Working Paper No. 3166. Washington, DC: World Bank.

Resti, A. 2000. Efficiency Measurement for Multi-Product Industries: A Comparison of Classic and Recent Techniques Based on Simulated Data. European Journal of Operational Research. 121 (3). pp. 559-78.

Sampaio de Sousa, M. and B. Stosic. 2005. Technical Efficiency of the Brazilian Municipalities: Correcting Nonparametric Frontier Measurements for Outliers. Journal of Productivity Analysis. 24 (2). pp. 157-81.

SMERU, 2004. When Teachers are Absent: Where do they go and what is the impact on students? Jakarta. http://microdata.worldbank.org/index.php/catalog/854/reports (accessed 30 January 2013).

Van de Sijpe, N. and G. Rayp. 2004. Measuring and Explaining Government Inefficiency in Developing Countries. Gent: Universiteit Gent. pp. 1-35.

World Bank. 2000. Kazakhstan Public Expenditure Review. Volume II: Main report. Washington, DC. http://www-wds.worldbank.org/external/default/WDSContentServer/WDSP/IB/2000/08/18/

0000 94946_00080205344466/Rendered/PDF/multi_page.pdf (accessed 30 January 2013).

- - 2000. Kazakhstan Public Expenditure Review. Volume III: Annexes and Statistical Appendix. Washington, DC. http://www-wds.worldbank.org/external/default/WDSContentServer/ WDSP/IB/2000/08/18/000094946_00080305310184/Rendered/PDF/multi_page.pdf (accessed 30 January 2013).

- - 2000. Malaysia Public Expenditure: Managing the Crisis, Challenging the Future. Washington, DC. Report No. 20371-MA http://www-wds.worldbank.org/external/default/ WDSContentServer/WDSP/IB/2000/07/07/000094946_00061605362942/Rendered/PDF/ multi_page.pdf (accessed 30 January 2013). 
- - . 2000. Nepal Public Expenditure Review. Volume III: Social Sectors. Report No. 20211-NEP. Washington, DC. http://www-wds.worldbank.org/external/default/WDSContentServer/ WDSP/IB/2000/06/24/000094946_00060205382699/Rendered/PDF/multi_page.pdf (accessed 30 January 2013).

- - 2000. Nepal Public Expenditure Review. Volume IV: Transport Sector. Report No. 20211NEP. Washington, DC. http://www-wds.worldbank.org/external/default/WDSContentServer/ WDSP/IB/2000/06/24/000094946_0006020538260/Rendered/PDF/multi_page.pdf (accessed 30 January 2013).

- - 2000. Thailand Public Finance in Transition. Report No. 20656-TH. Washington, DC. http://www-wds.worldbank.org/external/default/WDSContentServer/WDSP/IB/2000/11/10/ 000094946_00102705335740/Rendered/PDF/multi_page.pdf (accessed 30 January 2013).

- - - 2000. Viet Nam: Managing Public Resources Better. Volume I: Main Report. Report No. 21021-VN. Washington, DC. http://www-wds.worldbank.org/external/default/WDSContent Server/WDSP/IB/2001/01/06/000094946_00121905412341/Rendered/PDF/multi_page.pdf (accessed 30 January 2013).

- - 2000. Viet Nam: Managing Public Resources Better. Volume II: annexes. Report No. 21021VN. Washington DC. http://www-wds.worldbank.org/external/default/WDSContent Server/WDSP/IB/2001/01/06/000094946_00121905412342/Rendered/PDF/multi_page.pdf (accessed 30 January 2013).

- - 2 2001. Growing Healthy: A review of Vietnam's Health Sector. Report No. 22210-VN. Washington, DC. http://www-wds.worldbank.org/external/default/WDSContentServer/ WDSP/IB/2001/08/04/000094946_01072104005686/Rendered/PDF/multiOpage.pdf (accessed 30 January 2013).

-_-. 2002. Maldives Public Expenditure Review. Report No. 24238-MV. http://wwwwds.worldbank.org/external/default/WDSContentServer/WDSP/IB/2003/03/14/000094946 _03011004002111/Rendered/PDF/multiOpage.pdf (accessed 30 January 2013).

- - - 2002. China National Development and Sub-national Finance. A Review of Provincial Expenditures. Report No. 22951-CHA. Washington, DC. http://www-wds.worldbank .org/external/default/WDSContentServer/WDSP/IB/2002/05/14/000094946_0204300401 5663/Rendered/PDF/multiOpage.pdf (accessed 30 January 2013).

-_- 2002. Georgia Public Expenditure Review. Report No. 22913-GE. Washington, DC. http://www-wds.worldbank.org/external/default/WDSContentServer/WDSP/IB/2003/01/07/ 000094946_02122104005440/Rendered/PDF/multiOpage.pdf (accessed 30 January 2013).

- - - 2003. Public Expenditure Review of Armenia. Report No. 26973. Washington, DC. http://www-wds.worldbank.org/servlet/WDSContentServer/IW3P/IB/2003/10/16/000012009 _20031016113727/Rendered/PDF/269730PAPEROPublicOExpenditure0Armenia.pdf (accessed 30 January 2013). 
-_- 2003. Azerbaijan Public Expenditure Review. Report No. 25233-AZ. Washington, DC. http://www-wds.worldbank.org/external/default/WDSContentServer/WDSP/IB/2003/05/13/ 000094946_03043004015981/Rendered/PDF/multiOpage.pdf (accessed January 2013).

- - 2003. Bangladesh Public Expenditure Review. Report No. 24370-BD. Washington, DC. http://www-wds.worldbank.org/external/default/WDSContentServer/WDSP/IB/2003/08/01/ 000094946_03071904003640/Rendered/PDF/multiOpage.pdf (accessed 30 January 2013).

- - - 2003. Cambodia Enhancing Service Resource Delivery through Improved Resource Allocation and Institutional Reform. Report No. 25611-KH. Cambodia Resident Mission. http://wwwwds.worldbank.org/external/default/WDSContentServer/WDSP/IB/2003/09/24/ 000090341_20030924104425/Rendered/PDF/256110KH.pdf (accessed 30 January 2013).

-_- 2003. Papua New Guinea: Public Expenditure Review and Rationalization. Report No. 31209. Washington, DC. http://www-wds.worldbank.org/external/default/WDSContentServer/ WDSP/IB/2005/01/12/000009486_20050112122446/Rendered/PDF/312060PNGOwhit1iew OP07979801public1.pdf (accessed 30 January 2013).

- - - 2003. Philippines: Improving Government Performance: Discipline, Efficiency and Equity in Managing Public Resources. Philippines. http://www-wds.worldbank.org/ external/default/WDSContentServer/WDSP/IB/2003/07/25/000094946_03071704132781/ Rendered/PDF/multiOpage.pdf (accessed 30 January 2013).

- - . 2004. Kyrgyz Republic Public Expenditure Review. Volume I: Main Report. Washington, DC. http://www-wds.worldbank.org/external/default/WDSContentServer/WDSP/IB/2004/03/30/ 000012009_20040330102821/Rendered/PDF/281230V1.pdf (accessed 30 January 2013).

- - - 2004. Pakistan Public Expenditure Management. Volume I: Strategic Issues and Reform Management. Washington, DC. http://www-wds.worldbank.org/external/default/ WDSContentServer/WDSP/IB/2004/02/06/000090341_20040206113547/Rendered/PDF/ 256650PK.pdf (accessed 30 January 2013).

- - - 2004. The Democratic Republic of Timor-Leste Public Expenditure Review. Report No. 27886-TP. http://www-wds.worldbank.org/external/default/WDSContentServer/WDSP/IB/ 2004/07/29/000160016_20040729122907/Rendered/PDF/278860TP.pdf (accessed 30 January 2013).

- - - 2004. Papua New Guinea: Public Expenditure and Service Delivery. Washington, DC. http://siteresources.worldbank.org/INTPUBSERV/Resources/PNG.PESD.Education.Final(G).j un.2004.pdf (accessed 30 January 2013).

- - - 2005. Tajikistan Public Expenditure and Institutional Review. Volume I: Main Document. http://www-wds.worldbank.org/external/default/WDSContentServer/WDSP/IB/2006/01/31/ 000160016_20060131173148/Rendered/PDF/348910TJOP074810coverOPEIR01public1.pdf (accessed 30 January 2013).

- - . 2005. Republic of Uzbekistan Public Expenditure Review. Report No. 31014-UZ. Washington, DC. http://www-wds.worldbank.org/external/default/WDSContentServer/WDSP/IB/2005/04/05/ 000012009_20050405092350/Rendered/PDF/310140UZ.pdf (accessed 30 January 2013). 
- - . 2005. Viet Nam: Managing Public Expenditure for Poverty Reduction and Growth. Volume II: Sectoral Issues. Report No. 30035-VN. Washington, DC. http://www-wds .worldbank.org/external/default/WDSContentServer/WDSP/IB/2005/05/20/000012009_20 050520102858/Rendered/PDF/300350VN.pdf (accessed 30 January 2013).

- - 2005. Cambodia: Public Expenditure Tracking Survey in Primary Education. Report No. 34911-KH. Washington DC. http://www.glp.net/c/document_library/get_file?p_l_id=10413 \&folderld=12858\&name=DLFE-704.pdf (accessed 30 January 2013).

- - 2006. Public Financing of Education in Mongolia: Equity and Efficiency Implications. Report No. 36979-MN. Washington, DC. http://pets.prognoz.com/prod/CountryProfile .aspx? $=137 \&$ su $=212$ (accessed 30 January 2013).

- - 2006. Sri Lanka Selected Public Expenditure Issues, 2003/2004. Washington, DC. http://www-wds.worldbank.org/external/default/WDSContentServer/WDSP/IB/2006/07/19/ 000090341_20060719111843/Rendered/PDF/366300LK.pdf (accessed 30 January 2013).

- - - 2007. Spending for Development. Making the Most of Indonesia's New Opportunities. Report No. 38772. http://www-wds.worldbank.org/external/default/WDSContentServer/ WDSP/IB/2007/08/27/000020953_20070827113556/Rendered/PDF/387720REVISED01e0 coverOPER01PUBLIC1.pdf (accessed 30 January 2013).

- - - 2007. Lao PDR Public Expenditure Review Integrated Fiduciary Assessment. Washington, DC. http://www-wds.worldbank.org/external/default/WDSContentServer/WDSP/IB/2007/ 06/27/000020439_20070627094302/Rendered/PDF/397910LA.pdf (accessed 30 January 2013).

- - - 2008. Investing in Indonesia's Health: Challenges and Opportunities for Future Public Spending. Jakarta. http://siteresources.worldbank.org/HEALTHNUTRITIONAND POPULATION/Resources/Peer-Reviewed-Publications/HPEREnglishFinal.pdf (accessed 30 January 2013).

-_- 2008. Tajikistan Second Programmatic Public Expenditure Review. Report No 43280-TJ. Washington, DC. http://www-wds.worldbank.org/external/default/WDSContentServer/ WDSP/IB/2008/11/23/000333038_20081123230953/Rendered/PDF/432800ESWOvol110B ox334099B01PUBLIC1.pdf (accessed 30 January 2013).

- - 2008. Lao PDR: Public Expenditure Tracking Survey in Primary Education and Primary Health. Report No. 39043-LA. http://www.google.com/url?sa=t\&rct=j\&q=\&esrc=s\&source =web\&cd=1\&ved=0CDMQFjAA\&url=http\%3A\%2F\%2Fpets.prognoz.com\%2Fprod\%2FGetZip DocPack.ashx\%3Fdata\%3D1095\%26survey\%3D210\%26zipName\%3DPublications\&ei=74i9UI WmN8W7iwLmqoBA\&usg=AFQjCNEoNYA3H3Su9NpK9RXu9ymqvdZzqA (accessed 30 January 2013).

- - - 2008. Tajikistan Second Programmatic Public Expenditure Review. Volume IV: Public Expenditure Tracking Survey Health Sector. Report No. 43280-TJ. Washington, DC. http://www-wds.worldbank.org/external/default/WDSContentServer/WDSP/IB/2008/11/23/ 
000333038_20081123232030/Rendered/PDF/432800ESWOvol110Box334099B01PUBLIC1. pdf (accessed 30 January 2013).

- - 2008. Tajikistan Second Programmatic Public Expenditure Review. Volume III: Public Expenditure Tracking Survey Education Sector. Report No. 43280-TJ. Washington, DC. http://www-wds.worldbank.org/external/default/WDSContentServer/WDSP/IB/2008/11/23/ 000333038_20081123231534/Rendered/PDF/432800ESWOvol110Box334099B01PUBLIC1. pdf (accessed 30 January 2013).

- - 2009. Decentralizing Indonesia: A regional public expenditure review overview report. Report No. 26191-IND. Jakarta. http://siteresources.worldbank.org/HEALTHNUTRITIONAND POPULATION/Resources/Peer-Reviewed-Publications/HPEREnglishFinal.pdf (accessed 30 January 2013).

- - - 2009. Mongolia: Consolidating the Gain, Managing Booms and Busts, and Moving to Better Service Delivery. Volume I: Core Report. http://www-wds.worldbank.org/external/ default/WDSContentServer/WDSP/IB/2009/02/08/000333037_20090208230004/Render ed/PDF/433530ESWOMNOv1eb05020090Box334131B.pdf (accessed 30 January2013).

-_-. 2009. Philippines: Transport for Growth. Philippines. http://www-wds.worldbank.org/ external/default/WDSContentServer/WDSP/IB/2009/03/26/000334955_20090326035730/ Rendered/PDF/472810ESWOPH0G10Disclosed0031251091.pdf (accessed 30 January 2013).

-- - 2010. Nepal Public Expenditure Review. Report No. 55388-NP. Washington, DC. http://www-wds.worldbank.org/external/default/WDSContentServer/WDSP/IB/2012/06/14/ 000333038_20120614235827/Rendered/PDF/553880ESWOwhit00023B0PER020100Final. pdf\%20last\%20accessed\%20January\%2030 (accessed 30 January 2013).

- - - 2010. Working Paper 5 for Afghanistan Public Expenditure Review: Education Sector. Washington, DC. http://siteresources.worldbank.org/AFGHANISTANEXTN/Resources/ 305984-1264608805475/6739619-1276813833351/Paper5.pdf (accessed 30 January 2013).

- - - 2010. Bangladesh Public Expenditure and Institutional Review. Volume II: Sectoral Analysis. Report No. 47764-BD. Washington, DC. https://openknowledge.worldbank.org/ bitstream/handle/10986/2876/477670v20ESWOB1icialOUse0Only010910.pdf? sequence=1 (accessed 30 January 30 2013).

-—-. 2011. Philippines: Public Expenditure Review. Report No. 55695. Philippines. http://wwwwds.worldbank.org/external/default/WDSContentServer/WDSP/IB/2011/11/21/000356161_20 111121225449/Rendered/PDF/556950ESWOP1220ilOPublicOexpOreview.pdf (accessed 30 January 2013).

-_- 2011. Public Expenditure Review for the Solomon Islands Government. Report No. 68826. Washington, DC. http://www-wds.worldbank.org/external/default/WDSContentServer/ WDSP/IB/2012/05/22/000427087_20120522161243/Rendered/PDF/688260ESWOP1180ec hnicalOsummary0v4.pdf (accessed 30 January 2013). 
World Bank and Australian Aid, 2012. Philippines: Basic Education Public Expenditure Review. Report No. 71272. Philippines. http://www-wds.worldbank.org/external/default/WDSContentServer/ WDSP/IB/2012/09/25/000386194_20120925010910/Rendered/PDF/712720ESWOwhitOiscl osed09024020120l.pdf (accessed 30 January 2013).

World Health Organization (WHO). 2000. Health Systems: Improving Performance. Geneva: World Health Organization.

_- - 2010. Health Systems Financing: The Path to Universal Coverage. World Health Report 2010.

- - - 2011. The Fiji Islands: Health System Review. Manila: Asia Pacific Observatory. http://www2 .wpro.who.int/asia_pacific_observatory/resources/FijilslandsHealthSystemsReview-FINAL.pdf

Yaisawarng, S. and J. D. Klein. 1994. The Effects of Sulfur Dioxide Controls on Productivity Change in the U.S. Electric Power Industry. Review of Economics and Statistics. 76 (3). pp. 447-60.

Yunos, J. and D. Hawdon. 1997. The Efficiency of the National Electricity Board in Malaysia: An Intercountry Comparison. Energy Economics. 19 (2). pp. 255-69. 


\section{Public Service Spending: Efficiency and Distributional Impact-Lessons from Asia}

Efficiency and equity are cornerstone concepts in rational service delivery in the public sector. This paper benchmarks efficiency and equity in public spending on health, education, and social protection in a broad group of Asian Development Bank (ADB) member economies with varying levels of development. We describe public expenditure trends in health, education, and social protection in the region. Following Herrera and Pang (2005), we conduct a formal efficiency benchmarking exercise using Data Envelopment Analysis and available input and output data from World Development Indicators, Government Finance Statistics, and ADB databases to deconstruct each member economy's efficiency changes in health and education spending. We next turn to review service provision inequality within $\mathrm{ADB}$ economies using utilization rates and benefit incidence, and note the deficiency of pro-poor spending in some sectors.

\section{About the Asian Development Bank}

ADB's vision is an Asia and Pacific region free of poverty. Its mission is to help its developing member countries reduce poverty and improve the quality of life of their people. Despite the region's many successes, it remains home to the majority of the world's poor. ADB is committed to reducing poverty through inclusive economic growth, environmentally sustainable growth, and regional integration.

Based in Manila, ADB is owned by 67 members, including 48 from the region. Its main instruments for helping its developing member countries are policy dialogue, loans, equity investments, guarantees, grants, and technical assistance. 